\title{
Genome-wide analysis of mono-, di- and trimethylation of histone H3 lysine 4 in Arabidopsis thaliana

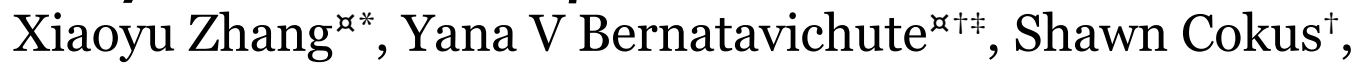 Matteo Pellegrini ${ }^{\dagger}$ and Steven E Jacobsen ${ }^{\dagger} \S$
}

Addresses: * Department of Plant Biology, University of Georgia, Green Street, Athens, GA 30602, USA. ${ }^{\star}$ Department of Molecular, Cell and Developmental Biology, University of California, Los Angeles, Charles E Young Drive South, Los Angeles, CA 90095, USA. ${ }^{*}$ Molecular Biology Institute, University of California, Los Angeles, Charles E Young Drive South, Los Angeles, CA 90095, USA. §Howard Hughes Medical Institute, University of California, Los Angeles, Charles E Young Drive South, Los Angeles, CA 90095, USA.

$\ltimes$ These authors contributed equally to this work.

Correspondence: Xiaoyu Zhang. Email: xiaoyu@plantbio.uga.edu. Steven E Jacobsen. Email: Jacobsen@ucla.edu

Published: 9 June 2009

Genome Biology 2009, 10:R62 (doi:10.1 186/gb-2009-10-6-r62)

The electronic version of this article is the complete one and can be found online at http://genomebiology.com/2009//0/6/R62
Received: 29 October 2008

Revised: 3 February 2009

Accepted: 9 June 2009

(C) 2009 Zhang et al.; licensee BioMed Central Ltd.

This is an open access article distributed under the terms of the Creative Commons Attribution License (http://creativecommons.org/licenses/by/2.0), which permits unrestricted use, distribution, and reproduction in any medium, provided the original work is properly cited.

\begin{abstract}
Background: Post-translational modifications of histones play important roles in maintaining normal transcription patterns by directly or indirectly affecting the structural properties of the chromatin. In plants, methylation of histone $\mathrm{H} 3$ lysine $4(\mathrm{H} 3 \mathrm{~K} 4 \mathrm{me})$ is associated with genes and required for normal plant development.

Results: We have characterized the genome-wide distribution patterns of mono-, di- and trimethylation of $\mathrm{H} 3 \mathrm{~K} 4$ ( $\mathrm{H} 3 \mathrm{~K} 4 \mathrm{mel}, \mathrm{H} 3 \mathrm{~K} 4 \mathrm{me} 2$ and $\mathrm{H} 3 \mathrm{~K} 4 \mathrm{me} 3$, respectively) in Arabidopsis thaliana seedlings using chromatin immunoprecipitation and high-resolution whole-genome tiling microarrays (ChIP-chip). All three types of $\mathrm{H} 3 \mathrm{~K} 4 \mathrm{me}$ are found to be almost exclusively genic, and two-thirds of Arabidopsis genes contain at least one type of H3K4me. H3K4me2 and H3K4me3 accumulate predominantly in promoters and 5 ' genic regions, whereas $\mathrm{H} 3 \mathrm{~K} 4 \mathrm{mel}$ is distributed within transcribed regions. In addition, $\mathrm{H} 3 \mathrm{~K} 4 \mathrm{me} 3$-containing genes are highly expressed with low levels of tissue specificity, but $\mathrm{H} 3 \mathrm{~K} 4 \mathrm{mel}$ or $\mathrm{H} 3 \mathrm{~K} 4 \mathrm{me} 2$ may not be directly involved in transcriptional activation. Furthermore, the preferential co-localization of $\mathrm{H} 3 \mathrm{~K} 4 \mathrm{me} 3$ and H3K27me3 found in mammals does not appear to occur in plants at a genome-wide level, but $\mathrm{H} 3 \mathrm{~K} 4 \mathrm{me} 2$ and H3K27me3 co-localize at a higher-than-expected frequency. Finally, we found that $\mathrm{H} 3 \mathrm{~K} 4 \mathrm{me} 2 / 3$ and DNA methylation appear to be mutually exclusive, but surprisingly, $\mathrm{H} 3 \mathrm{~K} 4 \mathrm{mel}$ is highly correlated with CG DNA methylation in the transcribed regions of genes.
\end{abstract}

Conclusions: H3K4me plays widespread roles in regulating gene expression in plants. Although many aspects of the mechanisms and functions of H3K4me appear to be conserved among all three kingdoms, we observed significant differences in the relationship between H3K4me and transcription or other epigenetic pathways in plants and mammals. 


\section{Background}

Post-translational modifications of histones play important roles in maintaining normal transcription patterns by directly or indirectly affecting the structural properties of the chromatin. Histone modifications are highly complex due to the large number of residues that can be modified as well as the variety of modification types (for example, methylation, acetylation, phosphorylation and ubiquitination, and so on) [1]. In addition, in the case of lysine methylation, a lysine residue can be mono-, di- or trimethylated with potentially different effects on chromatin structure [2-4]. Some histone modifications can directly alter chromatin structure. For example, acetylation of specific residues in the globular core domains of histones weakens the histone-DNA interactions, resulting in a relatively 'open' chromatin structure that facilitates transcription $[5,6]$. In contrast, other modifications (such as lysine methylation on the amino-terminal tail of $\mathrm{H}_{3}$ ) do not grossly affect chromatin structure per se, but interact with additional factors. For example, several groups of proteins have been shown to preferentially bind histone $\mathrm{H}_{3}$ methylated at lysine $4\left(\mathrm{H}_{3} \mathrm{~K} 4 \mathrm{me}\right)$ : the human chromatin remodeling and assembly factor hCHD1 (human homolog of Chromodomain helicase DNA binding protein 1) binds $\mathrm{H}_{3} \mathrm{~K} 4 \mathrm{me}$ through its chromodomain $[7,8]$, the chromatin remodeling complex NURF (Nucleosome remodeling factor) binds $\mathrm{H}_{3} \mathrm{~K} 4 \mathrm{me}$ through the PHD (plant homeodomain) domain of its large subunit BPTF (Bromodomain PHD finger transcription factor) [9], the $\mathrm{H}_{3} \mathrm{~K}_{9} \mathrm{me}_{3}$ and $\mathrm{H}_{3} \mathrm{~K}_{3} 6 \mathrm{me} 3$ demethylase JMJD2A (Jumonji domain containing 2A) binds $\mathrm{H}_{3} \mathrm{~K} 4 \mathrm{me}$ (and H4K2ome3) through its Tudor domain [10,11], and members of the ING (Inhibitor of growth) family of tumor suppressor proteins bind $\mathrm{H}_{3} \mathrm{~K} 4 \mathrm{me}$ through the $\mathrm{PHD}$ domain $[12,13]$.

Four lysine residues on histone $\mathrm{H}_{3}$ were found to be methylated in Arabidopsis thaliana by mass spectrometry studies ( $\mathrm{H}_{3} \mathrm{~K}_{4}, \mathrm{H}_{3} \mathrm{~K} 9, \mathrm{H}_{3} \mathrm{~K}_{2} 7$ and $\left.\mathrm{H}_{3} \mathrm{~K}_{3} 6\right)$ [14,15]. Di-methylation of histone $\mathrm{H}_{3}$ lysine 9 ( $\left.\mathrm{H}_{3} \mathrm{~K} 9 \mathrm{me} 2\right)$ is required for the transcriptional silencing of transposons and other repetitive sequences $[16,17]$, whereas $\mathrm{H}_{3} \mathrm{~K} 27 \mathrm{me} 3$ is primarily involved in the developmental repression of endogenous genes [18-21]. Recent genome-wide profiling studies in Arabidopsis have shown that $\mathrm{H}_{3} \mathrm{~K} 9 \mathrm{me} 2$ is highly enriched in the pericentromeric heterochromatin where transposons and other repeats cluster [22-25], whereas $\mathrm{H}_{3} \mathrm{~K} 27 \mathrm{me} 3$ is mostly distributed in the transcribed regions of a large number of euchromatic genes and bound by the chromodomain-containing protein LIKE HETEROCHROMATIN PROTEIN-1 (LHP1) $[23,26,27]$. $\mathrm{H}_{3} \mathrm{~K}_{3} 6 \mathrm{me}$ is required for normal plant development, but the genome-wide distribution of this modification and its role in transcriptional regulation remain unclear [2831]. Finally, $\mathrm{H}_{3} \mathrm{~K} 4 \mathrm{me} 2$ is primarily distributed in endogenous genes but not transcriptionally silent transposons, as shown by a previous study of a $1-\mathrm{Mb}$ heterochromatic region in Arabidopsis [22].
Only one $\mathrm{H}_{3} \mathrm{~K}_{4}$ methyltransferase (SET1; SET domain containing 1) has been identified in yeast (Saccharomyces cerevisiae), and it has been proposed the differential methylation of $\mathrm{H}_{3} \mathrm{~K}_{4}$ can be attributed to the kinetics of the dissociation of SET1 from the elongating RNA polymerase [32]. Multiple putative $\mathrm{H}_{3} \mathrm{~K}_{4}$ methyltransferases homologous to SET1 have been identified in Arabidopsis [33-36]. Several lines of evidence suggest that in Arabidopsis distinct $\mathrm{H}_{3} \mathrm{~K}_{4}$ methyltransferase complexes may also contribute to the differential accumulation of $\mathrm{H}_{3} \mathrm{~K}_{4} \mathrm{me} 1, \mathrm{H}_{3} \mathrm{~K}_{4} \mathrm{me} 2$ and $\mathrm{H}_{3} \mathrm{~K}_{4} \mathrm{me} 3$ at specific loci. For example, loss of the $\mathrm{H}_{3} \mathrm{~K}_{4}$ methyltransferase ATX1 (Arabidopsis homolog of Trithorax 1) leads to a mild reduction in global $\mathrm{H}_{3} \mathrm{~K}_{4} \mathrm{me}_{3}$ level and eliminates $\mathrm{H}_{3} \mathrm{~K}_{4} \mathrm{me}_{3}$ at specific loci, but has no detectable effect on $\mathrm{H}_{3} \mathrm{~K} 4 \mathrm{me} 2$ [37]. In contrast, the loss of a closely related $\mathrm{H}_{3} \mathrm{~K} 4$ methyltransferase, ATX2, results in locus-specific defects in $\mathrm{H}_{3} \mathrm{~K} 4 \mathrm{me} 2$ but does not appear to affect $\mathrm{H}_{3} \mathrm{~K}_{4} \mathrm{me} 3$ [38]. Examination of $\mathrm{H}_{3} \mathrm{~K} 4 \mathrm{me}$ levels at several genes revealed that the types of $\mathrm{H}_{3} \mathrm{~K} 4 \mathrm{me}$ present at individual genes may differ significantly $[38,39]$. Interestingly, the atx1 mutant exhibits several developmental abnormalities, whereas the atx2 mutant is phenotypically normal [38-40]. Furthermore, results from transcriptional profiling studies indicated that ATX1 and ATX2 likely regulate two largely non-overlapping sets of genes [38]. It therefore appears that there may be significant differences in the mechanism, localization and function $\mathrm{H}_{3} \mathrm{~K}_{4} \mathrm{me} 1, \mathrm{H}_{3} \mathrm{~K}_{4} \mathrm{me} 2$ and $\mathrm{H}_{3} \mathrm{~K}_{4} \mathrm{me}_{3}$.

Here we report a genome-wide analysis of $\mathrm{H}_{3} \mathrm{~K}_{4} \mathrm{me} 1$, $\mathrm{H}_{3} \mathrm{~K}_{4} \mathrm{me} 2$ and $\mathrm{H}_{3} \mathrm{~K}_{4} \mathrm{me}_{3}$ in Arabidopsis using chromatin immunoprecipitation (ChIP) and whole-genome tiling microarrays (ChIP-chip). We found that all three types of $\mathrm{H}_{3} \mathrm{~K} 4 \mathrm{me}$ are distributed exclusively within genes and their promoters, and that approximately two-thirds of genes contain at least one type of $\mathrm{H}_{3} \mathrm{~K}_{4}$ me. In addition, $\mathrm{H}_{3} \mathrm{~K}_{4} \mathrm{me}_{3}, \mathrm{H}_{3} \mathrm{~K}_{4} \mathrm{me} 2$ and $\mathrm{H}_{3} \mathrm{~K} 4 \mathrm{me} 1$ are distributed with a 5'-to-3' gradient along genes, where $\mathrm{H}_{3} \mathrm{~K}_{4} \mathrm{me}_{3}$ and $\mathrm{H}_{3} \mathrm{~K}_{4} \mathrm{me} 2$ are enriched in the promoters and 5 ' end of transcribed regions with $\mathrm{H}_{3} \mathrm{~K} 4 \mathrm{me} 3$ distributed slightly upstream of $\mathrm{H}_{3} \mathrm{~K}_{4} \mathrm{me}_{2}$, and $\mathrm{H}_{3} \mathrm{~K}_{4} \mathrm{me} 1$ is depleted in promoters but enriched in the transcribed regions with an apparent 3 ' bias. Interestingly, we found that genes associated with different combinations of $\mathrm{H}_{3} \mathrm{~K} 4 \mathrm{me}$ are expressed at different levels and with different degrees of tissue specificity. Furthermore, genome-wide comparisons between $\mathrm{H}_{3} \mathrm{~K} 4 \mathrm{me}$ and other epigenetic marks revealed preferential co-localization between $\mathrm{H}_{3} \mathrm{~K}_{4} \mathrm{me}_{2}$ and $\mathrm{H}_{3} \mathrm{~K}_{2} 7 \mathrm{me} 3$, and between $\mathrm{H}_{3} \mathrm{~K}_{4} \mathrm{me} 1$ and CG DNA methylation in the transcribed regions of genes. Finally, the relationship between $\mathrm{H}_{3}$ K4me and DNA methylation was further examined by genome-wide profiling of $\mathrm{H}_{3} \mathrm{~K} 4 \mathrm{me}$ in a DNA methylation mutant. The results suggested that $\mathrm{H}_{3} \mathrm{~K} 4 \mathrm{me}$ and DNA methylation may not directly interfere with each other in Arabidopsis, and that these two epigenetic pathways interact primarily through transcription. 


\section{Results and discussion Genome-wide profiling of $\mathrm{H} 3 \mathrm{~K} 4 \mathrm{mel}, \mathrm{H} 3 \mathrm{~K} 4 \mathrm{me} 2$ and H3K4me3}

Arabidopsis chromatin enriched for $\mathrm{H}_{3} \mathrm{~K} 4$ me was isolated by ChIP using antibodies that specifically recognize $\mathrm{H}_{3} \mathrm{~K} 4 \mathrm{me1}$, $\mathrm{H}_{3} \mathrm{~K}_{4} \mathrm{me} 2$ and $\mathrm{H}_{3} \mathrm{~K}_{4} \mathrm{me} 3$ (Figure $\mathrm{S} 1$ in Additional data file 1). As a control, nucleosomal DNA was isolated by ChIP using an antibody against histone $\mathrm{H}_{3}$ regardless of its modifications. $\mathrm{H}_{3} \mathrm{~K} 4 \mathrm{me}$ ChIP samples were compared to the control nucleosomal DNA by hybridization to Affymetrix whole-genome tiling microarrays that represent approximately $97 \%$ of the sequenced Arabidopsis genome at 35-bp resolution.

$\mathrm{H}_{3} \mathrm{~K}_{4} \mathrm{me} 1, \mathrm{H}_{3} \mathrm{~K} 4 \mathrm{me} 2$ and $\mathrm{H}_{3} \mathrm{~K}_{4} m e 3$ regions identified here are highly consistent with results from recently published studies [38] (Figure S2 in Additional data file 1). In addition, real-time PCR validations were performed at a number of randomly chosen loci, all of which yielded results consistent with the ChIP-chip data (Figure $\mathrm{S}_{3}$ in Additional data file 1). Finally, only $0.10 \%, 0.66 \%$ and $0.57 \%$ of the chloroplast genome was falsely identified as containing $\mathrm{H}_{3} \mathrm{~K} 4 \mathrm{me} 1$, $\mathrm{H}_{3} \mathrm{~K}_{4} \mathrm{me} 2$ and $\mathrm{H}_{3} \mathrm{~K}_{4} \mathrm{me}_{3}$, respectively. Taken together, these results indicate that the ChIP-chip data here provide an accurate representation of the genome-wide distribution of $\mathrm{H}_{3} \mathrm{~K} 4$ me with a relatively low false positive rate.

\section{H3K4mel, H3K4me2 and H3K4me3 accumulate exclusively in genes}

A total of $15,475(7.77 \mathrm{Mb}) \mathrm{H}_{3} \mathrm{~K} 4 \mathrm{me1}, 12,781$ (7.17 Mb) $\mathrm{H}_{3} \mathrm{~K} 4 \mathrm{me} 2$ and 15,894 (14.48 Mb) $\mathrm{H}_{3} \mathrm{~K}_{4}$ me3 regions were identified as described above, representing $6.45 \%, 6.0 \%$ and $12.1 \%$ of the sequenced nuclear genome, respectively. All three types of $\mathrm{H}_{3} \mathrm{~K} 4 \mathrm{me}$ are highly enriched in the gene-rich euchromatin and absent from pericentromeric heterochromatin regions where transposons and other repetitive sequences cluster (Figure 1a). Such a euchromatic distribution may largely reflect the fact that $\mathrm{H}_{3} \mathrm{~K}_{4} \mathrm{me}_{1}, \mathrm{H}_{3} \mathrm{~K}_{4} \mathrm{me} 2$ and $\mathrm{H}_{3} \mathrm{~K} 4 \mathrm{me} 3$ localize almost exclusively in genes: $96.7 \%$, 93.3\% and $95.7 \%$ of all $\mathrm{H}_{3} \mathrm{~K}_{4} \mathrm{me} 1, \mathrm{H}_{3} \mathrm{~K}_{4} \mathrm{me} 2$ and $\mathrm{H}_{3} \mathrm{~K}_{4} \mathrm{me} 3$ regions, respectively, are in or overlap with transcribed regions of genes or their promoters (defined as the 200-bp regions upstream of transcription start sites). Only a small fraction of the remaining $\mathrm{H}_{3} \mathrm{~K}_{4} \mathrm{me}_{1}, \mathrm{H}_{3} \mathrm{~K}_{4} \mathrm{me} 2$ and $\mathrm{H}_{3} \mathrm{~K}_{4} \mathrm{me}_{3}$ regions (o.6\%, $1.3 \%$ and $1.5 \%$ of total, respectively) overlap with intergenic repetitive sequences such as transposons. The distribution of HK4me in a representative eukaryotic region is shown in Figure 1b.

\section{Differential distribution of $\mathrm{H} 3 \mathrm{~K} 4 \mathrm{mel}$, H3K4me2 and H3K4me3 within genes}

A total of 18,233 genes (approximately $68.0 \%$ of all annotated genes) were found to contain $\mathrm{H}_{3} \mathrm{~K}_{4} \mathrm{me}$ in their promoters and/or transcribed regions, including 8,571 with $\mathrm{H}_{3} \mathrm{~K} 4 \mathrm{me}$, 10,396 with $\mathrm{H}_{3} \mathrm{~K} 4 \mathrm{me} 2$ and 14,712 with $\mathrm{H}_{3} \mathrm{~K} 4 \mathrm{me}$. The distribution patterns of $\mathrm{H}_{3} \mathrm{~K} 4 \mathrm{me}$ at the $5^{\prime}$ regions of genes were determined by aligning genes by their transcription start sites, and the percentage of genes containing $\mathrm{H}_{3} \mathrm{~K} 4 \mathrm{me}$ in their promoters and the $5^{\prime}$ transcribed regions was determined. Similarly, the distribution patterns of $\mathrm{H}_{3} \mathrm{~K} 4 \mathrm{me}$ at the 3 ' regions of genes were determined by aligning genes by the 3 ' end of their transcribed regions. These analyses were performed on a set of 5,809 genes that meet the following two criteria. First, they are located $1 \mathrm{~kb}$ or more away from the upstream and downstream genes such that ambiguity introduced by neighboring genes can be minimized. Second, they are longer than $1 \mathrm{~kb}$ so that there is sufficient gene space to determine the distribution of $\mathrm{H}_{3} \mathrm{~K} 4 \mathrm{me}$. We further classified the 5,809 genes into four groups according to their length: long genes ( $>4 \mathrm{~kb}, 691$ genes), intermediate genes ( 3 to $4 \mathrm{~kb}$, 828 genes; 2 to $3 \mathrm{~kb}, 1,768$ genes) and short genes (1 to $2 \mathrm{~kb}$, 2,522 genes).

The distribution patterns of $\mathrm{H}_{3} \mathrm{~K} 4 \mathrm{me}$ on long genes are shown in Figure 2a. $\mathrm{H}_{3} \mathrm{~K}_{4} \mathrm{me} 1$ is present at relatively low level at the $5^{\prime}$ and 3 ' termini of transcribed regions, but is enriched in the internal regions with a slight $3^{\prime}$ bias. In contrast, $\mathrm{H}_{3} \mathrm{~K}_{4} \mathrm{me} 2$ and $\mathrm{H}_{3} \mathrm{~K}_{4} \mathrm{me} 3$ are both enriched in the 5 ' end with $\mathrm{H}_{3} \mathrm{~K}_{4} \mathrm{me} 3$ distributed slightly upstream of $\mathrm{H}_{3} \mathrm{~K}_{4}$ me2. Both $\mathrm{H}_{3} \mathrm{~K}_{4} \mathrm{me} 2$ and $\mathrm{H}_{3} \mathrm{~K}_{4} \mathrm{me}_{3}$ are also enriched in the promoters (200 bp upstream of transcription start sites) and 5' flanking regions (200 to approximately 400 bp upstream of transcription start sites), but are absent in the 3 ' half of the transcribed regions or the 3 ' flanking regions of the long genes.

A comparison of the distribution patterns of $\mathrm{H}_{3} \mathrm{~K}_{4}$ me on long genes and intermediate or short genes revealed several common features as well as some interesting differences. First, as gene length decreases, significantly smaller fractions of genes were found to contain $\mathrm{H}_{3} \mathrm{~K}_{4}$ me1, but the relative position of $\mathrm{H}_{3} \mathrm{~K} 4 \mathrm{me} 1$ in genes (that is, internal regions with a 3 ' bias) remains similar. Second, the distribution patterns of both $\mathrm{H}_{3} \mathrm{~K}_{4} \mathrm{me} 2$ and $\mathrm{H}_{3} \mathrm{~K}_{4} \mathrm{me} 3$ at the 5 ' ends of short or intermediate genes are largely similar to those on long genes, although the shortest genes seem to contain a lower level of $\mathrm{H}_{3} \mathrm{~K} 4 \mathrm{me} 3$ at the 5 ' end. Third, as gene length decreases, significantly more genes were found to contain $\mathrm{H}_{3} \mathrm{~K}_{4} \mathrm{me} 2$ and $\mathrm{H}_{3} \mathrm{~K}_{4}$ me3 in their 3 ' regions. For example, in the last $200 \mathrm{bp}, 10.8$ - and 13.3-fold more short genes contain $\mathrm{H}_{3} \mathrm{~K}_{4} \mathrm{me}_{2}$ and $\mathrm{H}_{3} \mathrm{~K}_{4}$ me3 than long genes, respectively.

In order to obtain a more continuous view of the distribution of $\mathrm{H}_{3} \mathrm{~K} 4 \mathrm{me}$, we analyzed the average distribution levels of $\mathrm{H}_{3} \mathrm{~K} 4 \mathrm{me}$ across entire genes. To do this, we divided the transcribed region of each gene into 20 bins $(5 \%$ of the gene length per bin), and divided the 1-kb upstream and downstream flanking regions of each gene into 20 bins ( 50 bp per bin). The percentage of genes containing $\mathrm{H}_{3} \mathrm{~K}_{4}$ me in each bin was then determined (Figure 2b). Consistent with the results described above, $\mathrm{H}_{3} \mathrm{~K} 4 \mathrm{me} 1$ is highly enriched within the transcribed regions, but it is present at very low levels in promoters and $3^{\prime}$ flanking regions. In addition, $\mathrm{H}_{3} \mathrm{~K}_{4} \mathrm{me}_{1}$ is present at significantly higher levels and spans broader regions on 


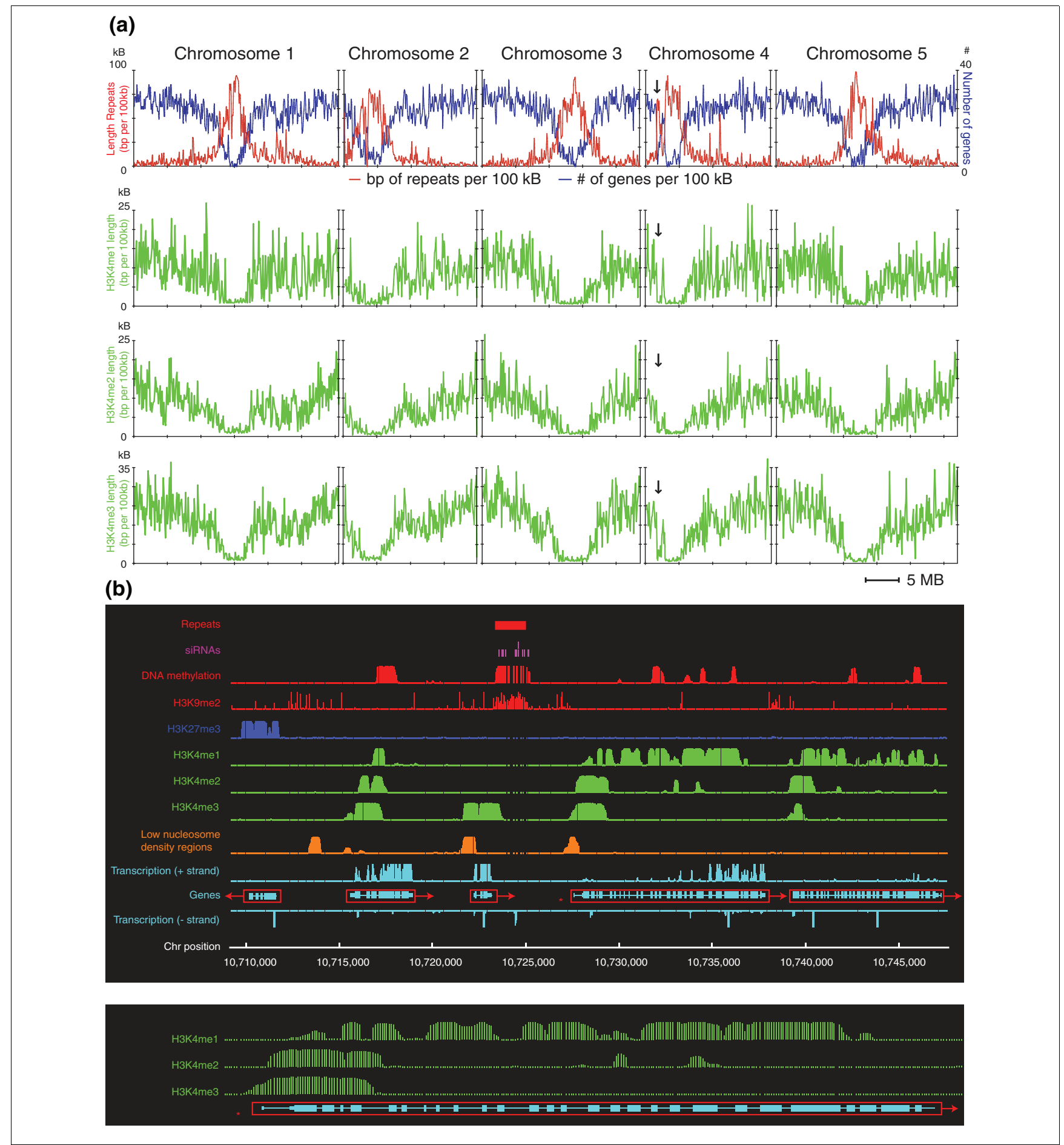

\section{Figure I}

Distribution of H3K4me in the Arabidopsis genome. (a) Chromosomal distribution of H3K4me. Top row: the total length of repetitive sequences (y-axis, left-side scale) and number of genes per $100 \mathrm{~kb}$ ( $\mathrm{y}$-axis, right-side scale). Bottom panels: chromosomal distribution of H3K4mel, H3K4me2 and H3K4me3. $X$-axis: chromosomal position; $y$-axis: the total length of genomic regions containing H3K4mel, H3K4me2 and H3K4me3 per $100 \mathrm{~kb}$, respectively. Arrows indicate the heterochromatic knob on chromosome 4. (b) Local distribution of H3K4mel, H3K4me2, H3K4me3, other epigenetic marks (DNA methylation, $\mathrm{H} 3 \mathrm{~K} 9 \mathrm{me} 2, \mathrm{H} 3 \mathrm{~K} 27 \mathrm{me} 3$, nucleosome density, small RNAs) and transcription activity in an approximately 40-kb euchromatic region on chromosome I. Repetitive sequences are shown as filled red boxes on top. Individual genes are shown in open red boxes (arrows indicate direction of transcription; filled light blue boxes, exons; light blue lines, introns). Distribution of H3K4me on the gene labeled by a red asterisk is enlarged and shown in detail at the bottom. 


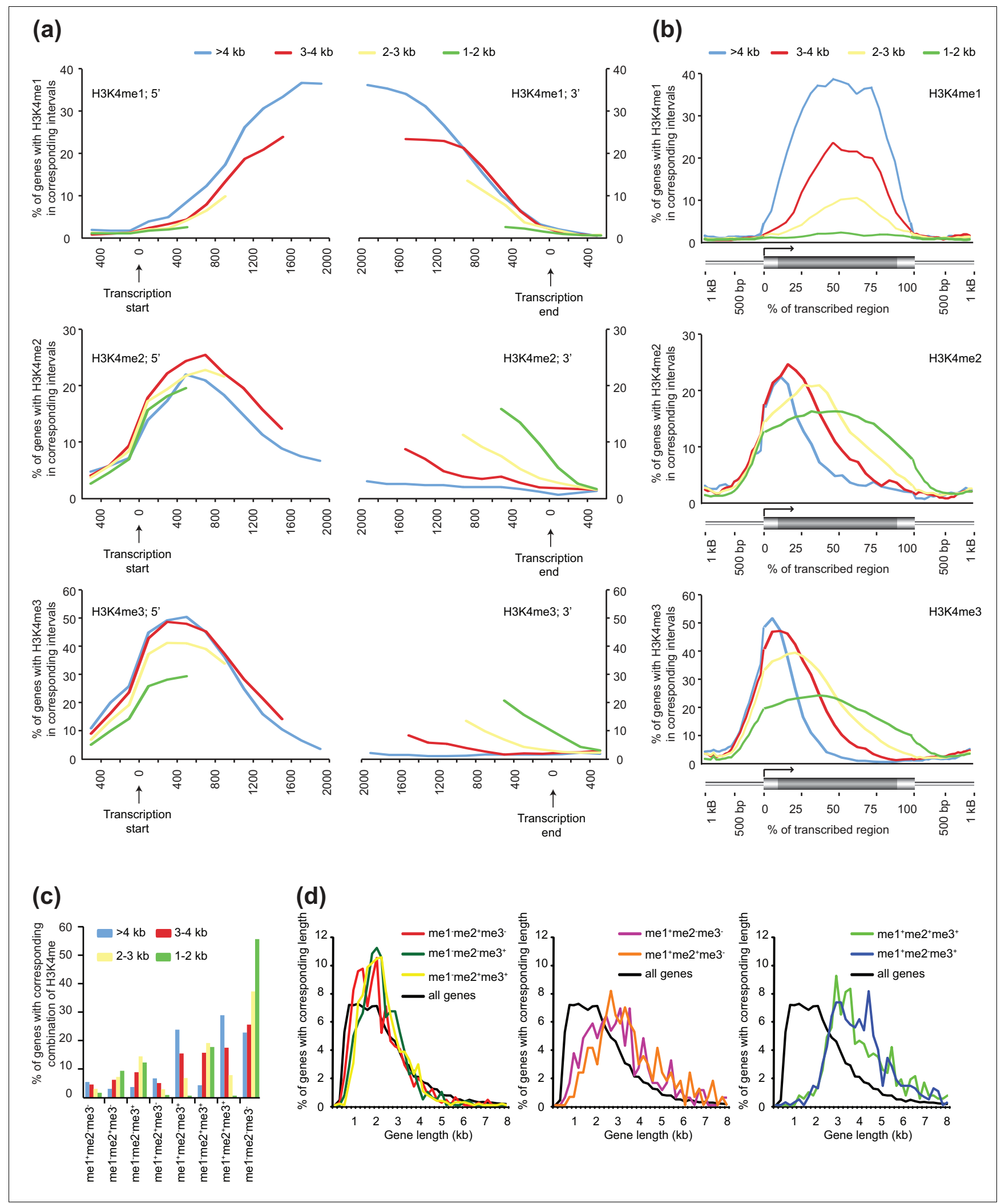

Figure 2 (see legend on next page) 
Figure 2 (see previous page)

Distribution of H3K4me relative to genes. (a) Distribution of $\mathrm{H} 3 \mathrm{~K} 4 \mathrm{me}$ at the 5 ' and 3 ' ends of genes. 'Isolated' genes are divided into four groups according to their length (see text for details). Genes belonging to each length group were aligned at the transcription start sites, and the percentage of genes containing $\mathrm{H} 3 \mathrm{~K} 4 \mathrm{me}$ in their promoters or 5 ' ends is determined at 200-bp intervals (left y-axis). Similarly, genes belonging to each length group were aligned at the end of transcribed regions, and the percentage of genes containing $\mathrm{H} 3 \mathrm{~K} 4 \mathrm{me}$ in their $3^{\prime}$ ends or downstream flanking regions is determined at 200-bp intervals (right y-axis). The first and last $500 \mathrm{bp}, \mathrm{I} \mathrm{kb}, \mathrm{I} .5 \mathrm{~kb}$ and $2 \mathrm{~kb}$ are shown for genes that are I to $2 \mathrm{~kb}, 2$ to $3 \mathrm{~kb}, 3$ to $4 \mathrm{~kb}$ and $>4 \mathrm{~kb}$ in length, respectively. (b) Distribution of $\mathrm{H} 3 \mathrm{~K} 4 \mathrm{me}$ across genes. Each gene (thick horizontal bar) was divided into 20 intervals (5\% each interval), and the $\mathrm{I}$ $\mathrm{kb}$ regions upstream and downstream of each gene (thin horizontal bars) were divided into 50 -bp intervals. The percentage of genes with $\mathrm{H} 3 \mathrm{~K} 27$ me 3 in each interval was graphed (y-axis). (c) Relationship between gene length and H3K4me. Genes are divided into eight categories according to the combination of $\mathrm{H} 3 \mathrm{~K} 4 \mathrm{me}$ (see text for details), and the percentage of genes within each length group that are associated with a particular combination of $\mathrm{H} 3 \mathrm{~K} 4 \mathrm{me}$ is shown (y-axis). (d) Length distribution of genes associated with different combinations of H3K4me. X-axis: gene length in kb (200 bp per bin); $y$-axis: the percentage of genes associated with a particular combination of H3K4me that are of the corresponding length. A small number of genes longer than $8 \mathrm{~kb}$ are not shown.

longer genes. In contrast, $\mathrm{H}_{3} \mathrm{~K}_{4} \mathrm{me}_{2}$ and $\mathrm{H}_{3} \mathrm{~K}_{4} \mathrm{me} 3$ are enriched in promoters and the 5 ' half of transcribed regions, at comparable levels on genes with different lengths. Although $\mathrm{H}_{3} \mathrm{~K}_{4} \mathrm{me} 2$ and $\mathrm{H}_{3} \mathrm{~K}_{4}$ me3 extend further towards the 3 ' end on shorter genes relative to gene length, the absolute positions remain virtually constant: regardless of gene length, the highest levels of $\mathrm{H}_{3} \mathrm{~K}_{4} \mathrm{me}_{2}$ and $\mathrm{H}_{3} \mathrm{~K}_{4} \mathrm{me}_{3}$ were found at approximately 600 to $800 \mathrm{bp}$ and 400 to $600 \mathrm{bp}$ downstream of transcription start sites, respectively (Figure 2a). In addition, for genes in all the length groups, $\mathrm{H}_{3} \mathrm{~K}_{4} \mathrm{me} 2$ and $\mathrm{H}_{3} \mathrm{~K}_{4} \mathrm{me} 3$ appear to be enriched (that is, present at the same or higher levels as they are at transcription start sites) downstream of transcription start sites for approximately 1.5 $\mathrm{kb}$ and $1 \mathrm{~kb}$, respectively (Figure $2 \mathrm{a}$ ).

The observation that $\mathrm{H}_{3} \mathrm{~K}_{4} \mathrm{me} 2$ and $\mathrm{H}_{3} \mathrm{~K}_{4} \mathrm{me}_{3}$ appear to cover the 5 ' regions of genes for a relatively constant length suggests that the length of a given gene may affect the association of this gene with different types of $\mathrm{H}_{3} \mathrm{~K} 4 \mathrm{me}$, in particular $\mathrm{H}_{3} \mathrm{~K} 4 \mathrm{me}$. For example, while all three types of $\mathrm{H}_{3} \mathrm{~K}_{4} \mathrm{me}$ are positively correlated with gene length (Figure 2b), such a relationship is significantly more pronounced for $\mathrm{H}_{3} \mathrm{~K} 4 \mathrm{me}$. To further study the relationship between gene length and $\mathrm{H}_{3} \mathrm{~K} 4 \mathrm{me}$, we classified the 5,809 genes into 8 categories based on the 8 possible combinations of their associated H3K4me: H3K4me1 only (me1+me2-me3-), H3K4me2 only (me1-me2 ${ }^{+} \mathrm{me}^{-}$), $\mathrm{H}_{3} \mathrm{~K}_{4} \mathrm{me} 3$ only (me1-me2-me $3^{+}$), $\mathrm{H}_{3} \mathrm{~K}_{4} \mathrm{me} 1$ and $\mathrm{H}_{3} \mathrm{~K}_{4} \mathrm{me} 2$ but no $\mathrm{H}_{3} \mathrm{~K}_{4} \mathrm{me}_{3}$ (me1 ${ }^{+} \mathrm{me}^{+}{ }^{+} \mathrm{me}^{-}$), $\mathrm{H}_{3} \mathrm{~K}_{4} \mathrm{me} 1$ and $\mathrm{H}_{3} \mathrm{~K}_{4} \mathrm{me}_{3}$ but not $\mathrm{H}_{3} \mathrm{~K}_{4} \mathrm{me} 2$ (me1 $^{+} \mathrm{me2}^{-}$ $\mathrm{me}^{+}$), $\mathrm{H}_{3} \mathrm{~K}_{4} \mathrm{me} 2$ and $\mathrm{H}_{3} \mathrm{~K}_{4} \mathrm{me} 3$ but not $\mathrm{H}_{3} \mathrm{~K}_{4} \mathrm{me} 2$ (me1 ${ }^{-}$ $\mathrm{me}^{+} \mathrm{me}^{+}$), $\mathrm{H}_{3} \mathrm{~K}_{4} \mathrm{me} 1, \mathrm{H}_{3} \mathrm{~K}_{4} \mathrm{me} 2$ and $\mathrm{H}_{3} \mathrm{~K}_{4} \mathrm{me} 3$ $\left(\mathrm{me}^{+} \mathrm{me2}^{+} \mathrm{me}^{+}\right)$, and no H3K4me (me1-me2-me3-). The frequencies of occurrences of these combinations within each length group were then determined. As shown in Figure 2c, all combinations that include $\mathrm{H}_{3} \mathrm{~K}_{4} \mathrm{me1}$ (regardless of $\mathrm{H}_{3} \mathrm{~K}_{4} \mathrm{me} 2$ and $\mathrm{H}_{3} \mathrm{~K}_{4} \mathrm{me}_{3}$ ) showed a strong positive correlation with gene length, and all combinations of $\mathrm{H}_{3} \mathrm{~K}_{4} \mathrm{me} 2$ and $\mathrm{H}_{3} \mathrm{~K}_{4}$ me3 (in the absence of $\mathrm{H}_{3} \mathrm{~K}_{4} \mathrm{me1}$ ) showed a negative correlation with gene length. In addition, genes associated with $\mathrm{H}_{3} \mathrm{~K} 4 \mathrm{me} 1$ (me1 $^{+} \mathrm{me}^{-} \mathrm{me}^{-}$, $\mathrm{me}^{+} \mathrm{me}^{+} \mathrm{me}^{-}$, $\mathrm{me}^{+}{ }^{+} \mathrm{me}^{-}$ $\mathrm{me} 3^{+}, \mathrm{me} 1^{+} \mathrm{me} 2^{+} \mathrm{me} 3^{+}$) are generally longer than average, with $\mathrm{me} 1^{+} \mathrm{me} 2^{-m e} 3^{+}$and $\mathrm{me} 1^{+} \mathrm{me} 2^{+} \mathrm{me} 3^{+}$genes being signifi- cantly longer and including very few genes shorter than $2 \mathrm{~kb}$ (Figure 2d). In summary, by every measure, longer genes show higher levels of $\mathrm{H}_{3} \mathrm{~K} 4 \mathrm{me}$.

The distribution patterns of $\mathrm{H}_{3} \mathrm{~K}_{4} \mathrm{me} 2$ and $\mathrm{H}_{3} \mathrm{~K}_{4} \mathrm{me}_{3}$ described here are similar to results from analyzing genes on chromosomes 4 and 10 in rice [41]. That is, in both species, $\mathrm{H}_{3} \mathrm{~K}_{4} \mathrm{me} 2$ and $\mathrm{H}_{3} \mathrm{~K}_{4} \mathrm{me}_{3}$ are enriched in the promoters and the 5 ' ends of transcribed regions, with $\mathrm{H}_{3} \mathrm{~K} 4 \mathrm{me} 3$ peaking slightly upstream of $\mathrm{H}_{3} \mathrm{~K} 4 \mathrm{me} 2$ (at approximately 400 to 600 bp and approximately 600 to $800 \mathrm{bp}$ downstream of transcription start sites, respectively; Figure 2a). These results suggest that $\mathrm{H}_{3} \mathrm{~K}_{4}$ me2 and $\mathrm{H}_{3} \mathrm{~K}_{4}$ me3 may be involved in both transcription initiation and the early stages of transcription elongation. In contrast, the internal distribution of $\mathrm{H}_{3} \mathrm{~K} 4 \mathrm{me} 1$ observed here suggests that $\mathrm{H}_{3} \mathrm{~K}_{4} \mathrm{me1}$ might be primarily involved in the elongation step during the transcription of longer genes. Alternatively, the apparent preferential accumulation of $\mathrm{H}_{3} \mathrm{~K}_{4} \mathrm{me} 1$ in the transcribed regions may be because this modification is reduced at gene ends (that is, $\mathrm{H}_{3} \mathrm{~K}_{4}$ is preferentially di- or trimethylated at the $5^{\prime}$ ends and unmethylated at the 3 ' ends).

\section{Association of different combinations of H3K4me I, H3K4me2 and H3K4me3 with differential gene expression patterns}

To further test the relationship between $\mathrm{H}_{3} \mathrm{~K} 4 \mathrm{me}$ and transcription, we compared the expression level and tissue specificity of genes associated with different combinations of $\mathrm{H}_{3} \mathrm{~K} 4 \mathrm{me}$, using a previously published expression profiling dataset [42]. Of the 5,809 genes described above, 5,479 were analyzed here, as expression data were available for these genes. As shown in Figure 3a, me1 $1^{+} \mathrm{me}^{-} \mathrm{me} 3^{+}$, $\mathrm{me}^{+} \mathrm{me} 2^{+} \mathrm{me}^{+}$and ${ }^{+}{ }^{-} \mathrm{me} 2^{-} \mathrm{me} 3^{+}$genes are highly expressed, whereas $\mathrm{me}^{+} \mathrm{me} 2^{-} \mathrm{me} 3^{-}, \mathrm{me}^{-} \mathrm{me} 2^{+} \mathrm{me} 3^{-}$and $\mathrm{me} 1^{+} \mathrm{me} 2^{+} \mathrm{me} 3^{-}$genes are expressed at very low levels. The me1-me $2^{+} \mathrm{me}^{+}$group includes genes with a wide range of expression levels and seems to be enriched for moderately expressed genes. In addition, me1 $1^{+} \mathrm{me}^{-} \mathrm{me} 3^{+}$, $\mathrm{me}^{+} \mathrm{me}^{+} \mathrm{me} 3^{+}$and me1-me2-me $3^{+}$genes exhibit very low levels of tissue specificity, while $\mathrm{me1}^{+} \mathrm{me}^{-\mathrm{me}}{ }^{-}$, $\mathrm{me}^{-}$ me ${ }^{+}{ }^{+} 3^{-}$and $m e 1^{+}{ }^{-m e} 2^{+}$me $3^{-}$genes are highly tissue specific 


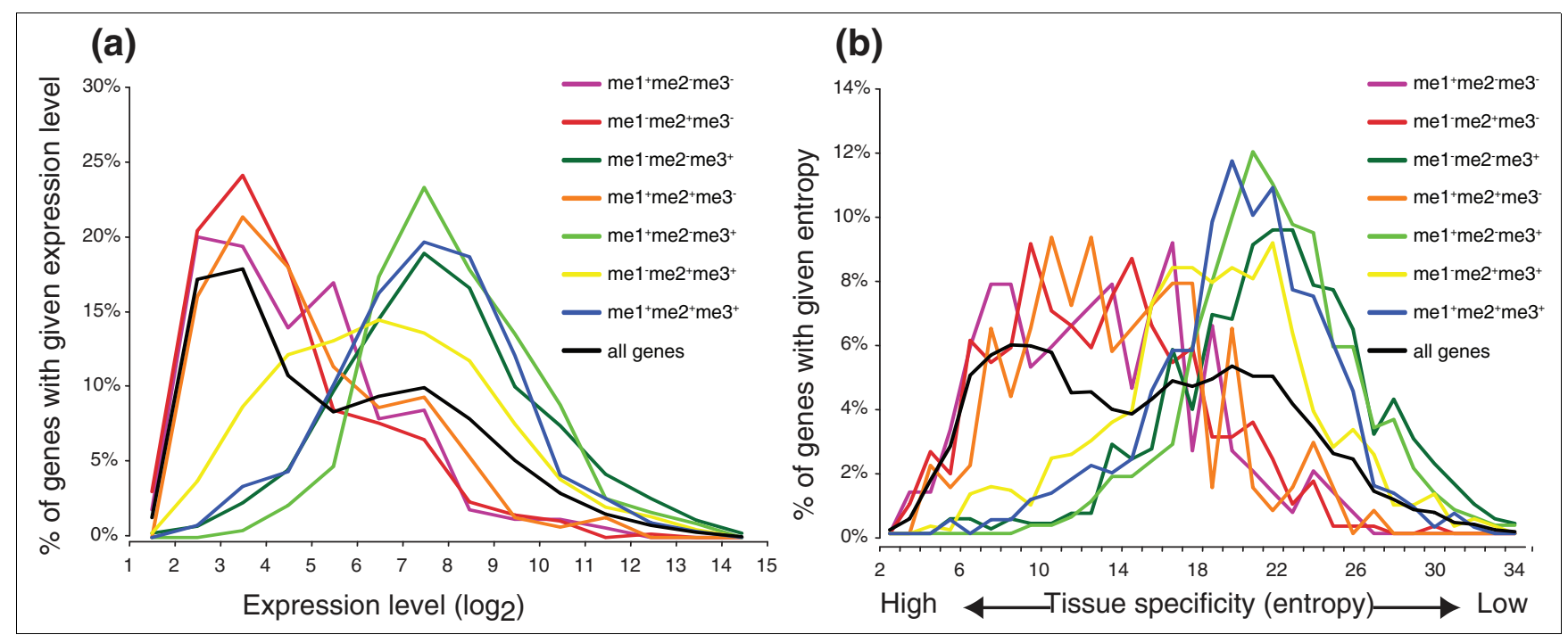

Figure 3

Genes with different expression levels and patterns are associated with different combinations of H3K4me. (a) Distribution of expression levels of genes associated with different combinations of $\mathrm{H} 3 \mathrm{~K} 4 \mathrm{me}$. X-axis: gene expression level determined in a previous study (log 2 scale) [42]. $\mathrm{Y}$-axis: the percentage of genes with corresponding $\mathrm{H} 3 \mathrm{~K} 4 \mathrm{me}$ combination and expression level. (b) The degree of tissue-specific expression of genes associated with different combinations of $\mathrm{H} 3 \mathrm{~K} 4 \mathrm{me}$, as measured by entropy (x-axis). Y-axis: the percentage of genes with corresponding $\mathrm{H} 3 \mathrm{~K} 4 \mathrm{me}$ combination and entropy values.

(Figure 3b). Taken together, these results suggest that $\mathrm{H}_{3} \mathrm{~K} 4 \mathrm{me} 3$ is associated with and likely plays important roles in active transcription. $\mathrm{H}_{3} \mathrm{~K}_{4} \mathrm{me} 1$ and $\mathrm{H}_{3} \mathrm{~K}_{4} \mathrm{me}_{2}$, in the absence of $\mathrm{H}_{3} \mathrm{~K}_{4} \mathrm{me} 3$, are preferentially associated with tissue-specific genes that are generally not expressed at the developmental stage assayed in this study. These results are consistent with previous reports that although $\mathrm{H}_{3} \mathrm{~K} 4 \mathrm{me} 2$ is generally associated with genes in Arabidopsis, its presence does not always correlate with active transcription [37].

\section{Relationship between H3K4me and H3K27me3}

In Drosophila, the Trithorax (TRX) family of $\mathrm{H}_{3} \mathrm{~K} 4$ methyltransferases and the Enhancer of Zeste (E(z)) family of $\mathrm{H}_{3} \mathrm{~K} 27$ methyltransferases function antagonistically to activate or repress a largely overlapping set of genes, respectively $[43,44]$. Interestingly, many genes are associated with both $\mathrm{H}_{3} \mathrm{~K} 4 \mathrm{me}$ and $\mathrm{H}_{3} \mathrm{~K} 27 \mathrm{me} 3$ in mammalian stem cells, and such a 'bivalent' histone modification has been suggested to play an important role in stem cell renewal and differentiation [45]. Similarly, the co-existence and antagonistic functions of $\mathrm{H}_{3} \mathrm{~K}_{4} \mathrm{me} 3$ and $\mathrm{H}_{3} \mathrm{~K} 27 \mathrm{me} 3$ have been described at the FLC and AGAMOUS genes in Arabidopsis [38,39,46-48]. We have indeed detected $\mathrm{H}_{3} \mathrm{~K}_{4} \mathrm{me}_{2}, \mathrm{H}_{3} \mathrm{~K}_{4} \mathrm{me} 3$ and $\mathrm{H}_{3} \mathrm{~K}_{2} 7 \mathrm{me} 3$ at the FLC gene. However, we found that AGAMOUS contains a low level of $\mathrm{H}_{3} \mathrm{~K}_{4} \mathrm{me} 2$ but no significant level of $\mathrm{H}_{3} \mathrm{~K} 4 \mathrm{me} 3$. This apparent discrepancy is likely due to the different tissues used in the experiments: young seedlings were used in this studywhereas a previous study used mature rosettes (Z Avramova, personal communication).

We have previously found that $\mathrm{H}_{3} \mathrm{~K} 27 \mathrm{me} 3$ is associated with 4,00o to 5,000 tissue-specific genes in their repressed state in Arabidopsis [26]. In order to test whether a preferential association of $\mathrm{H}_{3} \mathrm{~K} 4 \mathrm{me}$ with $\mathrm{H}_{3} \mathrm{~K}_{2}$ mese exists that could indicate a functional connection, we first determined the fraction of genes with each combination of $\mathrm{H}_{3} \mathrm{~K}_{4}$ me that are also associated with $\mathrm{H}_{3} \mathrm{~K} 27 \mathrm{me} 3$. As shown in Table 1, we found that ${ }^{-}{ }^{-m e} 2^{-m e} 3^{-}$and me1 $^{-m e 2^{+}}{ }^{-}{ }^{-} 3^{-}$genes are associated with $\mathrm{H}_{3} \mathrm{~K} 27 \mathrm{me} 3$ more frequently than expected. In addition, the association frequencies of me1+me2-me $3^{-}$, $\mathrm{me}^{+} \mathrm{me}^{+} \mathrm{me}^{-}$and $\mathrm{me}^{-} \mathrm{me} 2^{+} \mathrm{me} 3^{+}$genes with $\mathrm{H}_{3} \mathrm{~K} 27 \mathrm{me} 3$ are all lower than expected. Finally, me1-me $2^{-m e} 3^{+}$, $\mathrm{me}^{+} \mathrm{me} 2^{-\mathrm{me}} 3^{+}$, and $\mathrm{me} 1^{+} \mathrm{me} 2^{+} \mathrm{me} 3^{+}$genes are even more depleted of $\mathrm{H}_{3} \mathrm{~K}_{2} 7 \mathrm{me} 3$. It should be noted that the differences in transcription levels cannot fully account for the differential association of $\mathrm{H}_{3} \mathrm{~K}_{4}$ me genes with $\mathrm{H}_{3} \mathrm{~K} 27 m \mathrm{~m}_{3}$. For

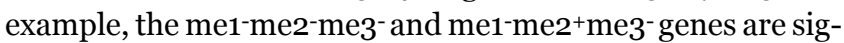
nificantly more frequently associated with $\mathrm{H}_{3} \mathrm{~K}_{2} 7 \mathrm{me} 3$ than me $1^{+}$me2-me $3^{-}$and $\mathrm{me}^{+}{ }^{+} \mathrm{me} 2^{+} \mathrm{me} 3^{-}$genes, but these four categories of genes are expressed at very similar levels (Figure 3). The relationship between $\mathrm{H}_{3} \mathrm{~K}_{4}$ me and $\mathrm{H}_{3} \mathrm{~K}_{2} 7 \mathrm{me} 3$ was further examined by directly testing whether they co-localize to the same genomic regions. To do this, we determined the presence of each type of $\mathrm{H}_{3} \mathrm{~K}_{4}$ me in $\mathrm{H}_{3} \mathrm{~K} 27$ me3-containing genomic regions. As a control, we also determined the presence of $\mathrm{H}_{3} \mathrm{~K} 4 \mathrm{me}$ in a set of randomly chosen regions with the same length and genomic distributions of $\mathrm{H}_{3} \mathrm{~K} 27 \mathrm{me} 3-\mathrm{con}-$ taining regions. As shown in Table 2, whereas $\mathrm{H}_{3} \mathrm{~K} 4 \mathrm{me} 1$ and $\mathrm{H}_{3} \mathrm{~K} 4 \mathrm{me} 3$ are significantly depleted in $\mathrm{H}_{3} \mathrm{~K} 27 \mathrm{me} 3$-containing regions, $\mathrm{H}_{3} \mathrm{~K} 4 \mathrm{me} 2$ was found to overlap with $\mathrm{H}_{3} \mathrm{~K} 27 \mathrm{me} 3$ slightly more frequently than with random control regions.

It should be noted that the starting materials in this study (young seedlings) included many distinct cell types. It is likely 
Table I

Co-localization of $\mathrm{H} 3 \mathrm{~K} 4 \mathrm{me}$ and $\mathrm{H} 3 \mathrm{~K} 27 \mathrm{me} 3$ in genes

\begin{tabular}{|c|c|c|c|c|c|}
\hline & Total & $\mathrm{H} 3 \mathrm{~K} 27 \mathrm{me} 3$ target genes & Observed & Enriched for $\mathrm{H} 3 \mathrm{~K} 27 \mathrm{me} 3$ target genes?* & Depleted of $\mathrm{H} 3 \mathrm{~K} 27 \mathrm{me} 3$ target genes? \\
\hline $\mathrm{mel}^{+} \mathrm{me} 2-\mathrm{me}^{-}$ & 179 & 31 & $17.32 \%$ & No $(P=1)$ & Yes $\left(P=1.6 \times 10^{-5}\right)$ \\
\hline mel-me2+me3- & 445 & 206 & $46.29 \%$ & Yes $\left(P<10^{-10}\right)$ & No $(P=1)$ \\
\hline mel-me2-me3+ & 675 & 69 & $10.22 \%$ & No $(P=1)$ & Yes $\left(P<10^{-10}\right)$ \\
\hline mel-me2+me3- & 171 & 33 & $19.30 \%$ & No $(P=1)$ & Yes $\left(P=3.0 \times 10^{-4}\right)$ \\
\hline $\mathrm{mel}^{+} \mathrm{me}^{-} \mathrm{me}^{+}$ & 437 & 14 & $3.20 \%$ & No $(P=1)$ & Yes $\left(P<10^{-10}\right)$ \\
\hline mel-me2 $2^{+} \mathrm{me}^{+}$ & 954 & 173 & $18.13 \%$ & No $(P=1)$ & Yes $\left(P<10^{-10}\right)$ \\
\hline $\mathrm{mel}^{+} \mathrm{me2}^{+} \mathrm{me}^{+}$ & 507 & 16 & $3.16 \%$ & No $(P=1)$ & Yes $\left(P<10^{-10}\right)$ \\
\hline mel-me2-me3- & $2,44 I$ & 1,266 & $51.86 \%$ & Yes $\left(P<10^{-10}\right)$ & No $(P=1)$ \\
\hline
\end{tabular}

*Of the 5,809 genes, $\mathrm{I}, 808$ (3I.12\%) contain $\mathrm{H} 3 \mathrm{~K} 27 \mathrm{me} 3$. If the localizations of $\mathrm{H} 3 \mathrm{~K} 4 \mathrm{me}$ and $\mathrm{H} 3 \mathrm{~K} 27 \mathrm{me} 3$ are independent of each other, roughly $31.12 \%$ of the genes with each $\mathrm{H} 3 \mathrm{~K} 4$ me combination should also contain $\mathrm{H} 3 \mathrm{~K} 27 \mathrm{me} 3$.

that some genes are associated with $\mathrm{H}_{3} \mathrm{~K} 4 \mathrm{me} 3$ when they are expressed in some cell types, but are associated with $\mathrm{H}_{3} \mathrm{~K} 27 \mathrm{~m} 3$ elsewhere when they are transcriptionally repressed. It is therefore possible that the low frequency of co-localization between $\mathrm{H}_{3} \mathrm{~K} 4 \mathrm{me} 3$ and $\mathrm{H}_{3} \mathrm{~K} 27 \mathrm{me} 3$ described here may still represent an overestimate. It is also possible, however, that co-localization of $\mathrm{H}_{3} \mathrm{~K}_{4} \mathrm{me}_{3}$ and $\mathrm{H}_{3} \mathrm{~K} 27 \mathrm{me} 3$ at a given gene only occurs in specific cell types or during certain developmental stages. If this is the case, our results generated using mixed cell types from a single development stage could represent a gross underestimate of the prevalence of bivalent chromatin modification in plants. Future studies at cell-specific levels should more directly address the exact extent to which plant genes are bivalently modified. In any event, our results seem to indicate a mutually exclusive relationship between $\mathrm{H}_{3} \mathrm{~K}_{4}$ me3 and $\mathrm{H}_{3} \mathrm{~K}_{2} 7 \mathrm{me} 3$ at many genes in Arabidopsis seedlings. In animals, the $\mathrm{H}_{3} \mathrm{~K}_{4}$ demethylase JARID1A (Jumonji, AT rich interactive domain 1A)/RBP2 (Retinol binding protein 2) is recruited to genomic targets through its interaction with the $\mathrm{H}_{3} \mathrm{~K} 27 \mathrm{me} 3$ methyltransferase complex Polycomb repressive complex (PRC) 2, where $\mathrm{RBP} 2$ mediates transcriptional repression by demethylating $\mathrm{H}_{3} \mathrm{~K}_{4} \mathrm{me}_{3}$ to $\mathrm{H}_{3} \mathrm{~K}_{4} \mathrm{me} 2$ (and to a lesser extent, $\mathrm{H}_{3} \mathrm{~K}_{4} \mathrm{me} 2$ to $\mathrm{H}_{3} \mathrm{~K} 4 \mathrm{me1}$ ) [49,5O]. In addition, the $\mathrm{H}_{3} \mathrm{~K} 4 \mathrm{me3}^{-}$-specific demethylase JARID1D interacts with Ring6a (Really interesting new gene 6a)/MBLR (Mel18 and Bmi1-like RING finger protein), which is closely related to the PRC1 components Bmi1 (B Lymphoma Mo-MLV insertion region 1) and Mel18
[51]. Interestingly, two Arabidopsis RING finger proteins, AtRING1a and AtRING1b, have been recently found to interact with the $\mathrm{H}_{3} \mathrm{~K} 27 \mathrm{me} 3$ methyltransferase CURLY LEAF and the $\mathrm{H}_{3} \mathrm{~K} 27 \mathrm{me}_{3}$-binding protein LIKE HETEROCHROMATIN PROTEIN1, and are required for the transcriptional repression of $\mathrm{H}_{3} \mathrm{~K} 27 \mathrm{me} 3$ target genes [52]. The general mutual exclusion between $\mathrm{H}_{3} \mathrm{~K}_{4} \mathrm{me}_{3}$ and $\mathrm{H}_{3} \mathrm{~K} 27 \mathrm{me} 3$ as well as the more frequent overlap of $\mathrm{H}_{3} \mathrm{~K}_{4} \mathrm{me} 2$ and $\mathrm{H}_{3} \mathrm{~K}_{2} 7 \mathrm{me} 3$ suggest that similar mechanisms might also function in plants. That is, plant $\mathrm{H}_{3} \mathrm{~K}_{4} \mathrm{me} 3$ demethylase(s) may function in transcriptional repression by interacting with PRC1 and/or PCR2. If this is the case, a fraction of the $\mathrm{H}_{3} \mathrm{~K} 4 \mathrm{me} 2$ in the Arabidopsis genome could be the demethylation product of $\mathrm{H}_{3} \mathrm{~K} 4 \mathrm{me}$.

We also observed that $\mathrm{H}_{3} \mathrm{~K} 4 \mathrm{me}$ tended not to co-localize with $\mathrm{H}_{3} \mathrm{~K} 27 \mathrm{me}$. One contributing factor could be the differential distribution patterns of these histone modifications along genes: $\mathrm{H}_{3} \mathrm{~K}_{4} \mathrm{me}_{1}$ tends to be present at the 3 ' half of long genes, whereas $\mathrm{H}_{3} \mathrm{~K} 27 \mathrm{me} 3$ does not exhibit similar preferences for either location within genes or gene length (Figure $\mathrm{S}_{4}$ in Additional data file 1). Furthermore, H3K4me1 was present more frequently on ubiquitously expressed housekeeping genes, while $\mathrm{H}_{3} \mathrm{~K}_{2} 7 \mathrm{~m}_{3}$ was more frequently present on tissue-specific genes.

Table 2

Co-localization of $\mathrm{H} 3 \mathrm{~K} 4 \mathrm{me}$ and $\mathrm{H} 3 \mathrm{~K} 27 \mathrm{me} 3$ in the same genome regions

\begin{tabular}{cccccccc}
\hline & Total regions & Overlap with H3K27me3 & $\%$ & Random overlapping* & Enriched for H3K27me3? & Depleted of H3K27me3? \\
\hline H3K4mel & 15,475 & 178 & 1.15 & $4.78 \%$ & No $(P=1)$ & Yes $\left(P<10^{-10}\right)$ \\
H3K4me2 & $12,78 \mathrm{I}$ & $88 \mathrm{I}$ & 6.89 & $6.09 \%$ & Yes $\left(P=1.0 \times 10^{-4}\right)$ & No $(P=1)$ \\
H3K4me3 & 15,894 & 572 & 3.60 & $7.12 \%$ & No $(P=1)$ & Yes $\left(P<10^{-10}\right)$ \\
\hline
\end{tabular}

*For each $\mathrm{H} 3 \mathrm{~K} 27$ me3-containing genomic region, a genomic region of the same length was randomly selected within its $10-\mathrm{kb}$ upstream or downstream flanking regions. The set of random control regions thus resemble the $\mathrm{H} 3 \mathrm{~K} 27 \mathrm{me} 3$ in both length and chromosomal distributions. The overlapping frequencies of the random control regions with $\mathrm{H} 3 \mathrm{~K} 4$ me-containing regions were then determined. 


\section{Relationship between H3K4me and DNA methylation} Cytosine DNA methylation is an epigenetic silencing mechanism important for the developmental regulation of endogenous genes and the transcriptional silencing of transposons [53-56]. A mechanistic relationship between DNA methylation and $\mathrm{H}_{3} \mathrm{~K}_{4}$ me has been described in mammals, where the DNA methyltransferase (DNMT) homolog DNMT3L specifically interacts with histone $\mathrm{H}_{3}$ containing unmethylated lysine 4 [57]. That DNMT3L also binds and stimulates the activity of the de novo DNA methyltransferase DNMT3A suggests that $\mathrm{H}_{3}$ with unmethylated $\mathrm{K}_{4}$ may play a role in targeting de novo DNA methylation in mammals [57-59]. However, a distinct small interfering RNA (siRNA)-directed pathway is responsible for de novo DNA methylation in plants [60-62], and an interaction between DNA methyltransferase and histone has not been reported.

Three DNA methylation pathways have been described in plants: METHYLTRANSFERASE 1 (MET1) is a homolog of mammalian DNMT1 and primarily functions in maintaining DNA methylation in the CG sequence context ('CG methylation') [63-66]. The DOMAIN REARRANGED METHYLASE (DRM) (homologous to mammalian DNMT3) interacts with the siRNA pathway and is required for de novo DNA methylation in all sequence contexts as well as the maintenance of DNA methylation in the $\mathrm{CHH}$ context $(\mathrm{H}=\mathrm{A}, \mathrm{C}$ or $\mathrm{T}$; ' $\mathrm{CHH}$ methylation') [60-62]. The CHROMOMETHYLASE3 is specific to plant genomes and interacts with the $\mathrm{H}_{3} \mathrm{~K} 9 \mathrm{me} 2$ pathway to maintain DNA methylation in the CHG sequence context ('CHG methylation') [67,68].

The genome-wide distribution of DNA methylation in Arabidopsis has been determined by a number of studies using microarray analyses or ultra-high-throughput deep sequencing of bisulfite treated DNA [22,25,69-77]. Results from these studies are largely consistent: $\mathrm{CG}, \mathrm{CHG}$ and $\mathrm{CHH}$ methylation is highly enriched in transposons and other repetitive sequences, suggesting that the RNA interference, H3K9me2 and DNA methylation pathways function together in the transcriptional repression at these loci. DNA methylation is generally depleted in the promoters and 5 ' ends of endogenous genes. However, over one-third of Arabidopsis genes contain DNA methylation exclusively in the CG sequence context that is enriched in the 3 ' half of their transcribed regions (termed 'body-methylation'). Most body-methylated genes are expressed at moderate to high levels, and it is therefore unclear whether CG methylation alone in the transcribed regions of genes plays a direct and significant repressive role in transcription.

In order to determine the relationship between DNA methylation and $\mathrm{H}_{3} \mathrm{~K}_{4}$ me in Arabidopsis, we compared DNA methylation levels in genomic regions containing $\mathrm{H}_{3} \mathrm{~K} 4 \mathrm{me}$ to the whole-genome average of DNA methylation. As shown in Table 3, CHG and CHH methylation is significantly depleted in genomic regions containing $\mathrm{H}_{3} \mathrm{~K}_{4} \mathrm{me} 1, \mathrm{H}_{3} \mathrm{~K} 4 \mathrm{me} 2$ or
Table 3

\begin{tabular}{|c|c|c|c|c|}
\hline $\mathrm{H} 3 \mathrm{~K} 4 \mathrm{me}$ & Chromosome & CG & $\mathrm{CHG}$ & $\mathrm{CHH}$ \\
\hline \multirow[t]{5}{*}{ H3K4mel } & I & $41.78 \%$ & $0.41 \%$ & $0.32 \%$ \\
\hline & 2 & $41.52 \%$ & $0.42 \%$ & $0.31 \%$ \\
\hline & 3 & $40.38 \%$ & $0.45 \%$ & $0.33 \%$ \\
\hline & 4 & $42.46 \%$ & $0.42 \%$ & $0.32 \%$ \\
\hline & 5 & $42.03 \%$ & $0.40 \%$ & $0.30 \%$ \\
\hline \multirow[t]{5}{*}{ H3K4me2 } & I & $4.22 \%$ & $0.39 \%$ & $0.32 \%$ \\
\hline & 2 & $4.11 \%$ & $0.38 \%$ & $0.34 \%$ \\
\hline & 3 & $3.89 \%$ & $0.39 \%$ & $0.33 \%$ \\
\hline & 4 & $4.78 \%$ & $0.36 \%$ & $0.33 \%$ \\
\hline & 5 & $4.32 \%$ & $0.38 \%$ & $0.32 \%$ \\
\hline \multirow[t]{5}{*}{ H3K4me3 } & I & $2.93 \%$ & $0.40 \%$ & $0.32 \%$ \\
\hline & 2 & $2.96 \%$ & $0.45 \%$ & $0.35 \%$ \\
\hline & 3 & $2.85 \%$ & $0.39 \%$ & $0.32 \%$ \\
\hline & 4 & $3.35 \%$ & $0.44 \%$ & $0.34 \%$ \\
\hline & 5 & $3.08 \%$ & $0.43 \%$ & $0.33 \%$ \\
\hline
\end{tabular}

*The genome-wide averages are: CG, 24.0\%; CHG, 6.7\%; $\mathrm{CHH}, \mathrm{I.7 \%}$.

$\mathrm{H}_{3} \mathrm{~K} 4 \mathrm{me}$. CG methylation is also significantly depleted in $\mathrm{H}_{3} \mathrm{~K} 4 \mathrm{me} 2-$ and $\mathrm{H}_{3} \mathrm{~K}_{4} \mathrm{me}_{3}-$ containing regions. In stark contrast, we found that CG methylation is highly enriched in $\mathrm{H}_{3} \mathrm{~K} 4 \mathrm{me}$-containing regions (Table 3 ). In addition, nearly two-thirds of $\mathrm{H}_{3} \mathrm{~K} 4 \mathrm{me} 1$-containing regions $(8,841$ of 14,599 , approximately 60.6\%) with two or more CG dinucleotides are methylated at two or more CG sites, compared to approximately $7.0 \%$ (842 of 12,100) and approximately $11.7 \%(1,750$ of 14,918) for $\mathrm{H}_{3} \mathrm{~K} 4 \mathrm{me} 2-$ and $\mathrm{H}_{3} \mathrm{~K}_{4} \mathrm{me}_{3}$-containing regions, respectively.

The low level of CHG and CHH methylation in $\mathrm{H}_{3} \mathrm{~K} 4 \mathrm{me}-\mathrm{Con}-$ taining regions can be explained by the virtual absence of siRNAs and $\mathrm{H}_{3}$ K9me2 within actively transcribed endogenous genes. The lack of $\mathrm{CG}$ methylation in $\mathrm{H}_{3} \mathrm{~K}_{4}$ me2- and $\mathrm{H}_{3} \mathrm{~K} 4 \mathrm{me} 3$-containing regions could be due to an active mutual exclusion mechanism (for example, MET1 may be discouraged from chromatin containing $\mathrm{H}_{3} \mathrm{~K}_{4} \mathrm{~m} 2$ or $\mathrm{H}_{3} \mathrm{~K}_{4} \mathrm{me}_{3}$ ) similar to what was recently described between DNA methylation and the deposition of the histone variant H2A.Z [78], or simply the differential localization of DNA methylation and $\mathrm{H}_{3} \mathrm{~K}_{4} \mathrm{me} 2 / \mathrm{H}_{3} \mathrm{~K}_{4} \mathrm{me} 3$ relative to genes (a $5^{\prime}$ bias for $\mathrm{H}_{3} \mathrm{~K}_{4} \mathrm{me} 2 / \mathrm{H}_{3} \mathrm{~K}_{4} \mathrm{me} 3$ and a 3 ' bias for DNA methylation). The high level of $\mathrm{CG}$ methylation in $\mathrm{H}_{3} \mathrm{~K} 4 \mathrm{me1}$-containing regions was unexpected. It is possible that $\mathrm{CG}$ methylation and $\mathrm{H}_{3} \mathrm{~K}_{4} \mathrm{me} 1$ interact with each other and therefore colocalize at the 3 ' transcribed regions of genes. It is also possible that the overlap of these two epigenetic marks merely reflects their preferential localization in the similar regions of highly expressed genes. In either case, these results indicate that CG methylation per se and $\mathrm{H}_{3} \mathrm{~K} 4 \mathrm{me} 1$ do not appear to 
interfere with each other. Finally, genomic regions free of $\mathrm{H}_{3} \mathrm{~K} 4 \mathrm{me}$ frequently lack DNA methylation, suggesting that the absence of $\mathrm{H}_{3} \mathrm{~K}_{4}$ me alone is insufficient to trigger DNA methylation.

\section{Ectopic H3K4me in met I is associated with transcriptional de-repression}

In order to test whether direct mechanistic links exist between DNA methylation and $\mathrm{H}_{3} \mathrm{~K}_{4}$ me (that is, whether DNA methylation per se excludes $\mathrm{H}_{3} \mathrm{~K}_{4} \mathrm{me}_{2} / \mathrm{H}_{3} \mathrm{~K}_{4} \mathrm{me}_{3}$ and whether gene body methylation facilitates $\mathrm{H}_{3} \mathrm{~K} 4 \mathrm{me}$ ), we determined the genome-wide distribution of $\mathrm{H}_{3} \mathrm{~K} 4 \mathrm{me}$ in the met1 mutant by ChIP-chip. Previous studies have shown that loss of MET1 eliminates CG methylation as well as substantial fractions of $\mathrm{CHG}$ and $\mathrm{CHH}$ methylation, resulting in massive transcriptional reactivation of transposons [71,72,74,76,77].

All three types of $\mathrm{H}_{3} \mathrm{~K} 4 \mathrm{me}$ were found to be present at much higher levels in the pericentromeric heterochromatin regions in met1 (Figure 4). A closer examination revealed that hyper$\mathrm{H}_{3} \mathrm{~K} 4 \mathrm{me}$ in met1 is almost always associated with ectopic over-expression of transposons or pseudogenes (Figure 4). However, the loss of DNA methylation does not appear to directly trigger hyper-H3K4me. In contrast to the transcrip-

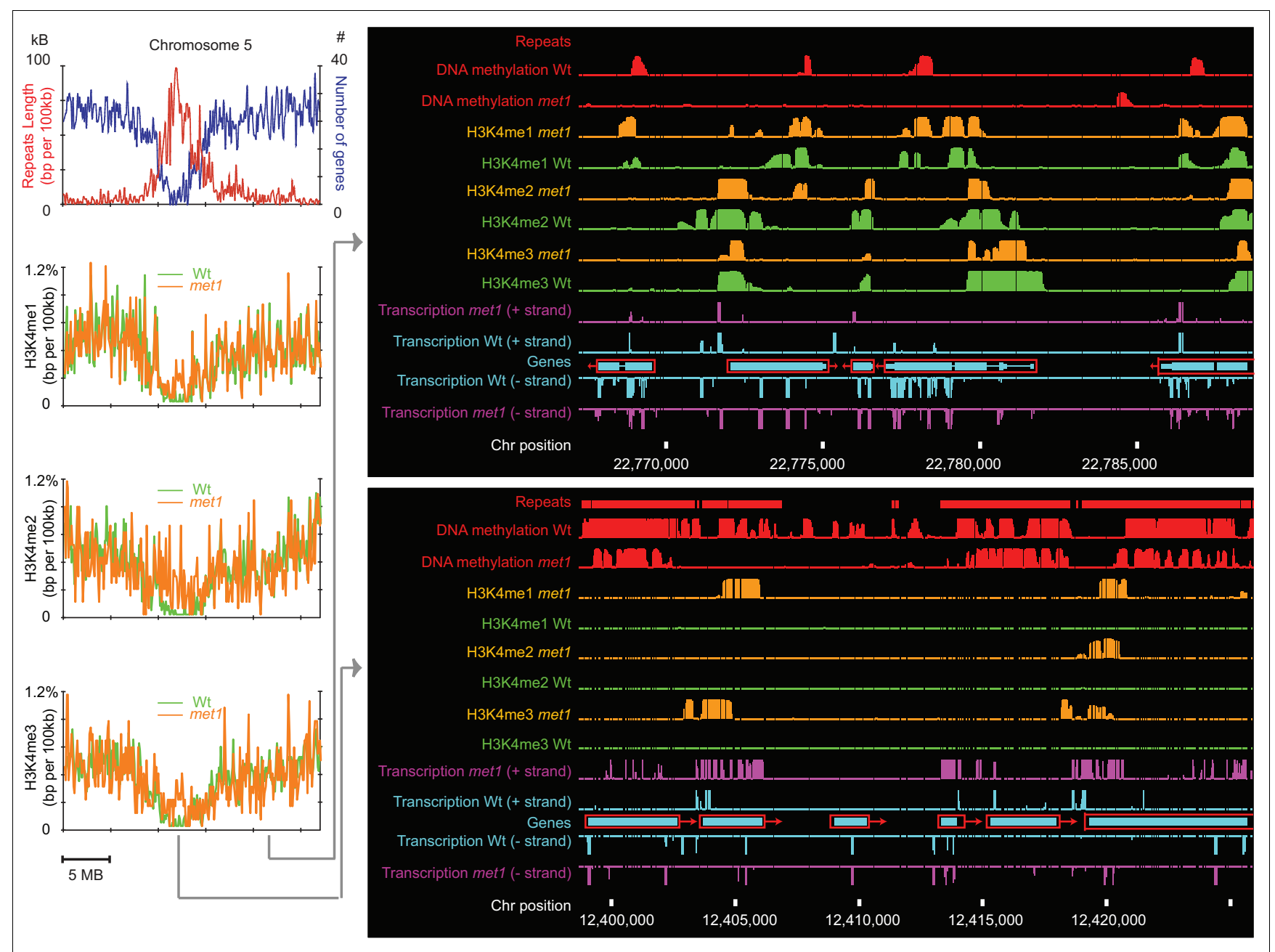

\section{Figure 4}

Comparisons of H3K4me accumulated in wild-type Arabidopsis (Wt, green) and the met I mutant (light brown). Left: chromosome-level changes in $\mathrm{H} 3 \mathrm{~K} 4 \mathrm{me}$, showing the ectopic accumulation of $\mathrm{H} 3 \mathrm{~K} 4 \mathrm{me}$ in the pericentromeric heterochromatin. Chromosome 5 is shown as an example (Wt, green; met I, light brown). X-axis: chromosome position; $y$-axis: the percentage of $\mathrm{H} 3 \mathrm{~K} 4 \mathrm{me}$ on chromosome 5 in the corresponding region (in I00 kb bins). Right: local changes in DNA methylation, H3K4me and transcription in a euchromatic region (top right) and a heterochromatic region (bottom right) on chromosome 5. The five genes shown in the euchromatic region likely encode cellular proteins and their expression patterns are unaffected in the met $I$ mutant. These are (from left to right): At5g56210, WPP-DOMAIN INTERACTING PROTEIN 2; At5g56220, nucleoside-triphosphatase; At5g56230, prenylated rab acceptor (PRAI) family protein; At5g56240, unknown protein. The six genes shown in the heterochromatic region are all transposonencoded genes. These are (from left to right): At5g32925, CACTA-like transposase; At5g32950, CACTA-like transposase, At5g32975, similar to En/Spmlike transposon protein; At5g33000, Transposable element gene; At5g33025, gypsy-like retrotransposon; At5g33050, gypsy-like retrotransposon. Note that the overexpression of At5g32950 and At5g33050 is associated with ectopic accumulation of H3K4me. 
tion-independent ectopic accumulation of H2A.Z in DNA hypomethylated regions in the met1 mutant [78], no major change in $\mathrm{H}_{3} \mathrm{~K} 4 \mathrm{me}$ was observed in genomic regions that are DNA-hypomethylated but not transcribed. This suggests that the ectopic transcriptional activity resulting from the loss of DNA methylation, but not the loss of DNA methylation per se, is associated with hyper-H3K4me. In addition, at nearly all genes, a complete loss of gene body methylation in met1 had no significant effect on $\mathrm{H}_{3} \mathrm{~K}_{4} \mathrm{me} 1, \mathrm{H}_{3} \mathrm{~K}_{4} \mathrm{me}_{2}$ or $\mathrm{H}_{3} \mathrm{~K}_{4} \mathrm{me} 3$ (Figure 4), suggesting that CG methylation in genes is dispensable for the normal accumulation of $\mathrm{H}_{3} \mathrm{~K} 4 \mathrm{me1}$.

\section{Conclusions}

Our genome-wide analysis of $\mathrm{H}_{3} \mathrm{~K}_{4} \mathrm{me} 1, \mathrm{H}_{3} \mathrm{~K} 4 \mathrm{me} 2$ and $\mathrm{H}_{3} \mathrm{~K} 4 \mathrm{me} 3$ led to several interesting results. First, a large number of genes were found to contain $\mathrm{H}_{3} \mathrm{~K} 4 \mathrm{me}$ : at a single developmental stage, approximately two-thirds of all Arabidopsis genes contain at least one type of $\mathrm{H}_{3} \mathrm{~K} 4 \mathrm{me}$. This suggests that $\mathrm{H}_{3} \mathrm{~K}_{4} \mathrm{me}$ may be required for the normal expression or a large number of genes in plants. Second, $\mathrm{H}_{3} \mathrm{~K}_{4} \mathrm{me} 1, \mathrm{H}_{3} \mathrm{~K}_{4} \mathrm{me} 2$ and $\mathrm{H}_{3} \mathrm{~K}_{4} \mathrm{me}_{3}$ are enriched in different regions in their target genes. $\mathrm{H}_{3} \mathrm{~K}_{4} \mathrm{me}_{2}$ and $\mathrm{H}_{3} \mathrm{~K}_{4} \mathrm{me}_{3}$ are distributed in the promoters and 5 ' regions with $\mathrm{H}_{3} \mathrm{~K}_{4} \mathrm{me}_{3}$ slightly more upstream, whereas $\mathrm{H}_{3} \mathrm{~K} 4 \mathrm{me} 1$ is mostly located within the transcribed regions. Our $\mathrm{H}_{3} \mathrm{~K}_{4} \mathrm{me} 3$ results are highly consistent with those recently published by van Nocker and colleagues [47]. Importantly, very similar distribution patterns of $\mathrm{H}_{3} \mathrm{~K}_{4} \mathrm{me} 1, \mathrm{H}_{3} \mathrm{~K}_{4} \mathrm{me} 2$ and $\mathrm{H}_{3} \mathrm{~K}_{4} \mathrm{me} 3$ were also found in yeast, human and other plants (for example, $\mathrm{H}_{3} \mathrm{~K} 4 \mathrm{me} 2$ and $\mathrm{H}_{3} \mathrm{~K}_{4} \mathrm{me} 3$ in rice) [32,41,79-81], which suggests that many aspects of the mechanisms and functions of $\mathrm{H}_{3} \mathrm{~K} 4 \mathrm{me}$ may be highly conserved during evolution. Third, we found that genes with different expression levels and tissue specificity are associated with different assortments of $\mathrm{H}_{3} \mathrm{~K}_{4} \mathrm{me} 1, \mathrm{H}_{3} \mathrm{~K}_{4} \mathrm{me} 2$ and $\mathrm{H}_{3} \mathrm{~K}_{4} \mathrm{me}_{3}$, suggesting that the three types of $\mathrm{H}_{3} \mathrm{~K}_{4}$ me may have different effects on chromatin structure and transcription. In particular, whereas $\mathrm{H}_{3} \mathrm{~K} 4 \mathrm{me} 3$ appears to be generally associated with actively transcribed genes, our results do not support a direct role of $\mathrm{H}_{3} \mathrm{~K}_{4} \mathrm{me} 1$ and $\mathrm{H}_{3} \mathrm{~K}_{4} \mathrm{me} 2$ in transcriptional activation: $\mathrm{H}_{3} \mathrm{~K}_{4} \mathrm{me} 1$ and $\mathrm{H}_{3} \mathrm{~K}_{4} \mathrm{me} 2$ do not appear to have an additive effect on $\mathrm{H}_{3} \mathrm{~K}_{4}$ me3 with regard to transcription levels and, in the absence of $\mathrm{H}_{3} \mathrm{~K}_{4} \mathrm{me}_{3}$, they are not preferentially associated with active transcription. Interestingly, our observation that $\mathrm{H}_{3} \mathrm{~K}_{4} \mathrm{me} 2$ (but not $\mathrm{H}_{3} \mathrm{~K}_{4} \mathrm{me}_{1}$ or $\mathrm{H}_{3} \mathrm{~K}_{4}$ me3) often overlaps with $\mathrm{H}_{3} \mathrm{~K} 27 \mathrm{me} 3$ raises the possibility that the accumulation of $\mathrm{H}_{3} \mathrm{~K}_{4} \mathrm{me} 2$ at some loci in the Arabidopsis genome might result from demethylation of $\mathrm{H}_{3} \mathrm{~K}_{4} \mathrm{me} 3$ by histone demethylases associated with PcG complexes. Fourth, unlike in mammalian stem cells, $\mathrm{H}_{3} \mathrm{~K}_{4} \mathrm{me} 3$ and $\mathrm{H}_{3} \mathrm{~K} 27 \mathrm{me} 3$ do not appear to preferentially co-localize on a genome-wide level in Arabidopsis. A second significant difference between plants and mammals is that, in mammals, $\mathrm{H}_{3} \mathrm{~K}_{4} \mathrm{me}_{3}$ is present at active promoters as well as a large number of 'poised' promoters [82], whereas in plants, the presence of $\mathrm{H}_{3} \mathrm{~K} 4 \mathrm{me} 3$ is usu- ally correlated with active transcription. Finally, we observed strong negative correlations between $\mathrm{H}_{3} \mathrm{~K}_{4} \mathrm{me} 2 / \mathrm{H}_{3} \mathrm{~K}_{4} \mathrm{me}_{3}$ and all three types of DNA methylation, and between $\mathrm{H}_{3} \mathrm{~K}_{4} \mathrm{me} 1$ and $\mathrm{CHG}$ and $\mathrm{CHH}$ DNA methylation. However, the loss of DNA methylation does not generally trigger hyper$\mathrm{H}_{3} \mathrm{~K} 4 \mathrm{me}$ in the corresponding genomic region, indicating that DNA methylation per se may not inhibit $\mathrm{H}_{3} \mathrm{~K} 4 \mathrm{me}$. Our results do suggest that DNA methylation may interfere with $\mathrm{H}_{3} \mathrm{~K} 4 \mathrm{me}$ indirectly through transcriptional repression, as ectopic transcription was observed in the vast majority of the cases where DNA hypomethylation and hyper-H3K4me occur at the same genes. Interestingly, $\mathrm{H}_{3} \mathrm{~K}_{4} \mathrm{me}_{1}$ is highly correlated with the CG methylation that exists within the transcribed regions of genes. Although the retention of $\mathrm{H}_{3} \mathrm{~K} 4 \mathrm{~m} 1$ in the met1 mutant indicates that CG DNA methylation is not required for the accumulation of $\mathrm{H}_{3} \mathrm{~K}_{4} \mathrm{me} 1$, it is possible that $\mathrm{H}_{3} \mathrm{~K} 4 \mathrm{me} 1$ might play a role in the colonization of CG DNA methylation within the transcribed regions of genes.

\section{Materials and methods}

Arabidopsis thaliana plants (accession Col) were grown on soil under continuous light for 3 weeks, and the aerial part of the seedlings was harvested. The met1-3 mutant plants were grown under the same conditions and harvested at a similar developmental stage. Chromatin was fragmented to 300 to $1,200 \mathrm{bp}$ (mostly 600 to $800 \mathrm{bp}$ ) by sonication, and ChIP was performed as previously described using antibodies purchased from Abcam (anti-H3K4me1, ab8895; anti$\mathrm{H}_{3} \mathrm{~K} 4 \mathrm{me2}$, ab7766; anti-H3K4me3, ab8580; anti-H3, ab1791) (Cambridge, MA, USA) [26]. The specificities of anti$\mathrm{H}_{3} \mathrm{~K} 4 \mathrm{me}$ antibodies were validated by dot blot analysis (Figure $\mathrm{S} 1$ in Additional data file 1). ChIP samples were amplified, labeled, and hybridized to microarrays as previously described [26,72]. Four biological replicates were performed for $\mathrm{H}_{3} \mathrm{~K}_{4} \mathrm{me} 1$ and $\mathrm{H}_{3} \mathrm{~K}_{4} \mathrm{me}_{3}$, and eight biological replicates were performed for $\mathrm{H}_{3} \mathrm{~K}_{4} \mathrm{me} 2$. For each $\mathrm{H}_{3} \mathrm{~K}_{4}$ me ChIP, an $\mathrm{H}_{3}$ ChIP was performed to isolate nucleosomal control DNA. Microarray hybridization intensities from probes that match a unique genomic region were analyzed using Tilemap with the Hidden Markov model option, as previously described [83]. All raw microarray data (CEL files) have been deposited in Gene Expression Omnibus [GEO:GSE13613]. Processed data showing the enrichment of $\mathrm{H}_{3} \mathrm{~K} 4 \mathrm{me}$ can be viewed online [84]. The gene expression data used here were from a previous comprehensive transcriptional profiling study (data for 7- to 14-day-old seedlings were used here for analysis of gene expression levels, and data for all tissue types and developmental stages were used here to analyze tissue specificity) [42]. The gene annotations used here are according to TAIR7. Real-time PCR validation of ChIP-chip results was performed using the SYBR Green I Master kit (Roche; Indianapolis, IN, USA) on a Roche Light Cycler 480. The PCR parameters are: 1 cycle of 10 minutes at $95^{\circ} \mathrm{C}, 40$ cycles of $10 \mathrm{~s}$ at $95^{\circ} \mathrm{C}, 10 \mathrm{~s}$ at $60^{\circ} \mathrm{C}$, and $20 \mathrm{~s}$ at $72^{\circ} \mathrm{C}$. PCR primer sequences are listed in Table $\mathrm{S} 1$ in Additional data file 1. 


\section{Abbreviations}

ATX: Arabidopsis homolog of Trithorax; ChIP: chromatin immunoprecipitation; DNMT: DNA methyltransferase; H3K4me: $\mathrm{H}_{3}$ methylated at lysine 4; JARID: Jumonji, AT rich interactive domain; MET1: METHYLTRANSFERASE 1 ; PHD: plant homeodomain; PRC: Polycomb repressive complex; RBP: Retinol binding protein; SET1: SET domain containing 1; siRNA: small interfering RNA.

\section{Authors' contributions}

XZ, YVB and SEJ designed the experiments. YVB and XZ performed the experiments. XZ, MP and SEJ analyzed the data. $\mathrm{SC}$ contributed reagents/materials/analysis tools. XZ wrote the paper.

\section{Additional data files}

The following additional data are available with the online version of this paper: Figures $\mathrm{S} 1$ to $\mathrm{S} 4$ and Table $\mathrm{S} 1$ (included in Additional data file 1).

\section{Acknowledgements}

$X Z$ was supported by a Faculty Research Grant (JR-040) from the University of Georgia. YVB was supported by USPHS National Research Service Award GM07I04. Jacobsen lab research was supported by $\mathrm{NIH}$ grant GM60398. SEJ is an investigator of the Howard Hughes Medical Institute.

\section{References}

I. Bhaumik SR, Smith E, Shilatifard A: Covalent modifications of histones during development and disease pathogenesis. Nat Struct Mol Biol 2007, I 4:1008-1016.

2. Schneider J, Wood A, Lee JS, Schuster R, Dueker J, Maguire C, Swanson SK, Florens L, Washburn MP, Shilatifard A: Molecular regulation of histone $\mathrm{H3}$ trimethylation by COMPASS and the regulation of gene expression. Mol Cell 2005, I 9:849-856.

3. Santos-Rosa H, Schneider R, Bannister AJ, Sherriff J, Bernstein BE, Emre NC, Schreiber SL, Mellor J, Kouzarides T: Active genes are tri-methylated at K4 of histone H3. Nature 2002, 4I9:407-4I I.

4. Wood A, Shukla A, Schneider J, Lee JS, Stanton JD, Dzuiba T, Swanson SK, Florens L, Washburn MP, Wyrick J, Bhaumik SR, Shilatifard A: Ctk complex-mediated regulation of histone methylation by COMPASS. Mol Cell Biol 2007, 27:709-720.

5. Williams SK, Truong D, Tyler JK: Acetylation in the globular core of histone $\mathrm{H} 3$ on lysine-56 promotes chromatin disassembly during transcriptional activation. Proc Natl Acad Sci USA 2008, 1 05:9000-9005.

6. Xu F, Zhang K, Grunstein M: Acetylation in histone $\mathbf{H 3}$ globular domain regulates gene expression in yeast. Cell 2005, | 2 I:375-385.

7. Sims RJ 3rd, Chen CF, Santos-Rosa H, Kouzarides T, Patel SS, Reinberg D: Human but not yeast CHDI binds directly and selectively to histone $\mathrm{H3}$ methylated at lysine 4 via its tandem chromodomains. J Biol Chem 2005, 280:4I789-4I792.

8. Flanagan JF, Mi LZ, Chruszcz M, Cymborowski M, Clines KL, Kim Y, Minor W, Rastinejad F, Khorasanizadeh S: Double chromodomains cooperate to recognize the methylated histone $\mathrm{H3}$ tail. Nature 2005, 438: I I8I-II85.

9. Wysocka J, Swigut T, Xiao H, Milne TA, Kwon SY, Landry J, Kauer M, Tackett AJ, Chait BT, Badenhorst P, Wu C, Allis CD: A PHD finger of NURF couples histone H3 lysine 4 trimethylation with chromatin remodelling. Nature 2006, 442:86-90.

10. Huang Y, Fang J, Bedford MT, Zhang Y, Xu RM: Recognition of histone $\mathrm{H} 3$ lysine-4 methylation by the double tudor domain of JMJD2A. Science 2006, 3 I 2:748-75 I.
II. Kim J, Daniel J, Espejo A, Lake A, Krishna M, Xia L, Zhang Y, Bedford MT: Tudor, MBT and chromo domains gauge the degree of lysine methylation. EMBO Rep 2006, 7:397-403.

12. Pena PV, Davrazou F, Shi X, Walter KL, Verkhusha VV, Gozani O, Zhao R, Kutateladze TG: Molecular mechanism of histone H3K4me3 recognition by plant homeodomain of ING2. Nature 2006, 442:100-103.

13. Shi X, Hong T, Walter KL, Ewalt M, Michishita E, Hung T, Carney D, Pena P, Lan F, Kaadige MR, Lacoste N, Cayrou C, Davrazou F, Saha A, Cairns BR, Ayer DE, Kutateladze TG, Shi Y, Cote J, Chua KF, Gozani O: ING2 PHD domain links histone H3 lysine 4 methylation to active gene repression. Nature 2006, 442:96-99.

14. Johnson L, Mollah S, Garcia BA, Muratore TL, Shabanowitz J, Hunt DF, Jacobsen SE: Mass spectrometry analysis of Arabidopsis histone $\mathrm{H3}$ reveals distinct combinations of post-translational modifications. Nucleic Acids Res 2004, 32:65 I I-65 I8.

I5. Zhang K, Sridhar VV, Zhu J, Kapoor A, Zhu JK: Distinctive core histone post-translational modification patterns in Arabidopsis thaliana. PLOS ONE 2007, 2:el210.

16. Jackson JP, Lindroth AM, Cao X, Jacobsen SE: Control of CpNpG DNA methylation by the KRYPTONITE histone $\mathbf{H 3}$ methyltransferase. Nature 2002, 4 I 6:556-560.

17. Malagnac F, Bartee L, Bender J: An Arabidopsis SET domain protein required for maintenance but not establishment of DNA methylation. EMBO J 2002, 2 I:6842-6852.

18. Schubert D, Clarenz O, Goodrich J: Epigenetic control of plant development by Polycomb-group proteins. Curr Opin Plant Biol 2005, 8:553-56I.

19. Lindroth AM, Shultis D, Jasencakova Z, Fuchs J, Johnson L, Schubert D, Patnaik D, Pradhan S, Goodrich J, Schubert I, Jenuwein T, Khorasanizadeh S, Jacobsen SE: Dual histone $\mathbf{H 3}$ methylation marks at lysines 9 and 27 required for interaction with CHROMOMETHYLASE3. EMBO J 2004, 23:4286-4296.

20. Kinoshita T, Harada J], Goldberg RB, Fischer RL: Polycomb repression of flowering during early plant development. Proc Natl Acad Sci USA 2001, 98:14156-14161.

21. Chanvivattana Y, Bishopp A, Schubert D, Stock C, Moon YH, Sung ZR, Goodrich J: Interaction of Polycomb-group proteins controlling flowering in Arabidopsis. Development 2004, | 3 |:5263-5276.

22. Lippman Z, Gendrel AV, Black M, Vaughn MW, Dedhia N, McCombie WR, Lavine K, Mittal V, May B, Kasschau KD, Carrington JC, Doerge RW, Colot V, Martienssen R: Role of transposable elements in heterochromatin and epigenetic control. Nature 2004, 430:47I-476.

23. Turck F, Roudier F, Farrona S, Martin-Magniette ML, Guillaume E, Buisine N, Gagnot S, Martienssen RA, Coupland G, Colot V: Arabidopsis TFL2/LHP I specifically associates with genes marked by trimethylation of histone $\mathbf{H 3}$ lysine 27. PLoS Genet 2007, 3:e86.

24. Bernatavichute $Y V$, Zhang $X$, Cokus S, Pellegrini M, Jacobsen SE: Genome-wide association of histone $\mathrm{H} 3$ lysine nine methylation with CHG DNA methylation in Arabidopsis thaliana. PLoS ONE 2008, 3:e3156.

25. Zhang $X$ : The epigenetic landscape of plants. Science 2008 , 320:489-492.

26. Zhang $X$, Clarenz $O$, Cokus $S$, Bernatavichute $Y V$, Pellegrini $M$, Goodrich J, Jacobsen SE: Whole-genome analysis of histone $\mathbf{H 3}$ lysine 27 trimethylation in Arabidopsis. PLOS Biol 2007, 5:e 129.

27. Zhang X, Germann S, Blus BJ, Khorasanizadeh S, Gaudin V, Jacobsen SE: The Arabidopsis LHP I protein colocalizes with histone H3 Lys27 trimethylation. Nat Struct Mol Biol 2007, I4:869-87I.

28. Zhao Z, Yu Y, Meyer D, Wu C, Shen WH: Prevention of early flowering by expression of FLOWERING LOCUS C requires methylation of histone H3 K36. Nat Cell Biol 2005, 7: I256-I260.

29. Kim SY, He Y, Jacob Y, Noh YS, Michaels S, Amasino R: Establishment of the vernalization-responsive, winter-annual habit in Arabidopsis requires a putative histone $\mathrm{H} 3$ methyl transferase. Plant Cell 2005, I 7:3301-3310.

30. Xu L, Zhao Z, Dong A, Soubigou-Taconnat L, Renou JP, Steinmetz A, Shen WH: Di- and tri- but not monomethylation on histone $\mathrm{H} 3$ lysine $\mathbf{3 6}$ marks active transcription of genes involved in flowering time regulation and other processes in Arabidopsis thaliana. Mol Cell Biol 2008, 28: I348-I360.

31. Dong G, Ma DP, Li J: The histone methyltransferase SDG8 regulates shoot branching in Arabidopsis. Biochem Biophys Res Commun 2008, 373:659-664.

32. Liu CL, Kaplan T, Kim M, Buratowski S, Schreiber SL, Friedman N, Rando OJ: Single-nucleosome mapping of histone modifica- 
tions in S. cerevisiae. PLoS Biol 2005, 3:e328.

33. Alvarez-Venegas R, Avramova Z: SET-domain proteins of the Su(var)3-9, E(z) and trithorax families. Gene 2002, 285:25-37.

34. Baumbusch LO, Thorstensen T, Krauss V, Fischer A, Naumann K, Assalkhou R, Schulz I, Reuter G, Aalen RB: The Arabidopsis thaliana genome contains at least 29 active genes encoding SET domain proteins that can be assigned to four evolutionarily conserved classes. Nucleic Acids Res 2001, 29:4319-4333.

35. Springer NM, Napoli CA, Selinger DA, Pandey R, Cone KC, Chandler VL, Kaeppler HF, Kaeppler SM: Comparative analysis of SET domain proteins in maize and Arabidopsis reveals multiple duplications preceding the divergence of monocots and dicots. Plant Physiol 2003, I32:907-925.

36. Zhao Z, Shen WH: Plants contain a high number of proteins showing sequence similarity to the animal SUV39H family of histone methyltransferases. Ann N Y Acad Sci 2004, | 030:66 |-669.

37. Alvarez-Venegas R, Avramova Z: Methylation patterns of histone H3 Lys 4, Lys 9 and Lys 27 in transcriptionally active and inactive Arabidopsis genes and in atx I mutants. Nucleic Acids Res 2005, 33:5199-5207.

38. Saleh A, Alvarez-Venegas R, Yilmaz M, Le O, Hou G, Sadder M, AlAbdallat A, Xia Y, Lu G, Ladunga I, Avramova Z: The highly similar Arabidopsis homologs of trithorax ATXI and ATX2 encode proteins with divergent biochemical functions. Plant Cell 2008, 20:568-579.

39. Pien S, Fleury D, Mylne JS, Crevillen P, Inze D, Avramova Z, Dean C, Grossniklaus U: ARABIDOPSIS TRITHORAXI dynamically regulates FLOWERING LOCUS C activation via histone 3 lysine 4 trimethylation. Plant Cell 2008, 20:580-588.

40. Alvarez-Venegas R, Pien S, Sadder M, Witmer X, Grossniklaus U, Avramova Z: ATX-I, an Arabidopsis homolog of trithorax, activates flower homeotic genes. Curr Biol 2003, I 3:627-637.

4l. Li X, Wang X, He K, Ma Y, Su N, He H, Stolc V, Tongprasit W, Jin W, Jiang J, Terzaghi W, Li S, Deng XW: High-resolution mapping of epigenetic modifications of the rice genome uncovers interplay between DNA methylation, histone methylation, and gene expression. Plant Cell 2008, 20:259-276.

42. Schmid M, Davison TS, Henz SR, Pape UJ, Demar M, Vingron M, Scholkopf B, Weigel D, Lohmann JU: A gene expression map of Arabidopsis thaliana development. Nat Genet 2005, 37:50I-506.

43. Papp B, Muller J: Histone trimethylation and the maintenance of transcriptional $O N$ and OFF states by trxG and PcG proteins. Genes Dev 2006, 20:2041-2054.

44. Beisel C, Buness A, Roustan-Espinosa IM, Koch B, Schmitt S, Haas SA Hild $M$, Katsuyama T, Paro R: Comparing active and repressed expression states of genes controlled by the Polycomb/ Trithorax group proteins. Proc Natl Acad Sci USA 2007, | 04:16615-16620.

45. Bernstein BE, Mikkelsen TS, Xie X, Kamal M, Huebert DJ, Cuff J, Fry B, Meissner A, Wernig M, Plath K, Jaenisch R, Wagschal A, Feil R, Schreiber SL, Lander ES: A bivalent chromatin structure marks key developmental genes in embryonic stem cells. Cell 2006, I 25:315-326.

46. Saleh A, Al-Abdallat A, Ndamukong I, Alvarez-Venegas R, Avramova Z: The Arabidopsis homologs of trithorax (ATXI) and enhancer of zeste (CLF) establish 'bivalent chromatin marks' at the silent AGAMOUS locus. Nucleic Acids Res 2007 35:6290-6296

47. Oh S, Park S, van Nocker S: Genic and global functions for Paf IC in chromatin modification and gene expression in Arabidopsis. PLoS Genet 2008, 4:el 000077.

48. Saleh A, Alvarez-Venegas R, Avramova Z: Dynamic and stable histone $\mathrm{H3}$ methylation patterns at the Arabidopsis FLC and API loci. Gene 2008, 423:43-47.

49. Pasini D, Hansen KH, Christensen J, Agger K, Cloos PA, Helin K: Coordinated regulation of transcriptional repression by the RBP2 H3K4 demethylase and Polycomb-Repressive Complex 2. Genes Dev 2008, 22: I345-1355.

50. Christensen J, Agger K, Cloos PA, Pasini D, Rose S, Sennels L, Rappsilber J, Hansen KH, Salcini AE, Helin K: RBP2 belongs to a family of demethylases, specific for tri-and dimethylated lysine 4 on histone 3. Cell 2007, I 28:1063-1076.

5I. Lee MG, Norman J, Shilatifard A, Shiekhattar R: Physical and functional association of a trimethyl H3K4 demethylase and Ring6a/MBLR, a polycomb-like protein. Cell 2007, I 28:877-887.

52. $\mathrm{Xu} \mathrm{L}$, Shen WH: Polycomb silencing of KNOX genes confines shoot stem cell niches in Arabidopsis. Curr Biol 2008, I 8:1966-197|.

53. Zhang X, Jacobsen SE: Genetic analyses of DNA methyltransferases in Arabidopsis thaliana. Cold Spring Harb Symp Quant Biol 2006, 71 : 439-447.

54. Zilberman D: The evolving functions of DNA methylation. Curr Opin Plant Biol 2008, I I:554-559.

55. Henderson IR, Jacobsen SE: Epigenetic inheritance in plants. Nature 2007, 447:4I8-424

56. Chan SW, Henderson IR, Jacobsen SE: Gardening the genome: DNA methylation in Arabidopsis thaliana. Nat Rev Genet 2005, 6:351-360.

57. Ooi SK, Qiu C, Bernstein E, Li K, Jia D, Yang Z, Erdjument-Bromage $H$, Tempst P, Lin SP, Allis CD, Cheng X, Bestor TH: DNMT3L connects unmethylated lysine 4 of histone $\mathrm{H} 3$ to de novo methylation of DNA. Nature 2007, 448:7|4-7/7.

58. Chen T, Ueda Y, Xie S, Li E: A novel Dnmt3a isoform produced from an alternative promoter localizes to euchromatin and its expression correlates with active de novo methylation. J Biol Chem 2002, 277:38746-38754.

59. Suetake I, Shinozaki F, Miyagawa J, Takeshima H, Tajima S: DNMT3L stimulates the DNA methylation activity of Dnmt3a and Dnmt3b through a direct interaction. I Biol Chem 2004, 279:27816-27823.

60. Cao X, Jacobsen SE: Role of the Arabidopsis DRM methyltransferases in de novo DNA methylation and gene silencing. Curr Biol 2002, I 2: I I38-1 | 44.

6I. Chan SW, Zilberman D, Xie Z, Johansen LK, Carrington JC, Jacobsen SE: RNA silencing genes control de novo DNA methylation. Science 2004, 303: 1336.

62. Zilberman D, Cao X, Jacobsen SE: ARGONAUTE4 control of locus-specific siRNA accumulation and DNA and histone methylation. Science 2003, 299:716-719.

63. Finnegan EJ, Peacock W], Dennis ES: Reduced DNA methylation in Arabidopsis thaliana results in abnormal plant development. Proc Natl Acad Sci USA 1996, 93:8449-8454.

64. Ronemus MJ, Galbiati M, Ticknor C, Chen J, Dellaporta SL: Demethylation-induced developmental pleiotropy in Arabidopsis. Science 1996, 273:654-657.

65. Kankel MW, Ramsey DE, Stokes TL, Flowers SK, Haag JR, Jeddeloh JA, Riddle NC, Verbsky ML, Richards EJ: Arabidopsis METI cytosine methyltransferase mutants. Genetics 2003, I 63: I I09-1 I 22

66. Saze H, Scheid OM, Paszkowski J: Maintenance of CpG methylation is essential for epigenetic inheritance during plant gametogenesis. Nat Genet 2003, 34:65-69.

67. Bartee L, Malagnac F, Bender J: Arabidopsis cmt3 chromomethylase mutations block non-CG methylation and silencing of an endogenous gene. Genes Dev 200I, I 5:I753-I758.

68. Lindroth $A M$, Cao $X$, Jackson JP, Zilberman $D$, McCallum CM, Henikoff S, Jacobsen SE: Requirement of CHROMOMETHYLASE3 for maintenance of CpXpG methylation. Science 200I, 292:2077-2080.

69. Tran RK, Henikoff JG, Zilberman D, Ditt RF, Jacobsen SE, Henikoff S DNA methylation profiling identifies CG methylation clusters in Arabidopsis genes. Curr Biol 2005, I 5: I 54-I 59.

70. Vaughn MW, Tanurd Ic $M$, Lippman Z, Jiang $H$, Carrasquillo $R$, Rabinowicz PD, Dedhia N, McCombie WR, Agier N, Bulski A, Colot V, Doerge RW, Martienssen RA: Epigenetic natural variation in Arabidopsis thaliana. PLoS Biol 2007, 5:e I74.

7I. Zilberman D, Gehring M, Tran RK, Ballinger T, Henikoff S: Genomewide analysis of Arabidopsis thaliana DNA methylation uncovers an interdependence between methylation and transcription. Nat Genet 2007, 39:6I-69.

72. Zhang $X$, Yazaki J, Sundaresan A, Cokus S, Chan SW, Chen H, Henderson IR, Shinn P, Pellegrini M, Jacobsen SE, Ecker JR: Genome-wide high-resolution mapping and functional analysis of DNA methylation in Arabidopsis. Cell 2006, I26: I 189-I201.

73. Reinders J, Delucinge Vivier C, Theiler G, Chollet D, Descombes $P$, Paszkowski J: Genome-wide, high-resolution DNA methylation profiling using bisulfite-mediated cytosine conversion. Genome Res 2008, 18:469-476

74. Mathieu O, Reinders J, Caikovski M, Smathajitt C, Paszkowski J: Transgenerational stability of the Arabidopsis epigenome is coordinated by CG methylation. Cell 2007, I 30:85 I-862.

75. Zilberman D, Henikoff S: Genome-wide analysis of DNA methylation patterns. Development 2007, I 34:3959-3965.

76. Cokus S], Feng S, Zhang X, Chen Z, Merriman B, Haudenschild CD, Pradhan S, Nelson SF, Pellegrini M, Jacobsen SE: Shotgun bisulphite 
sequencing of the Arabidopsis genome reveals DNA methylation patterning. Nature 2008, 452:215-219.

77. Lister R, O'Malley RC, Tonti-Filippini J, Gregory BD, Berry CC, Millar $\mathrm{AH}$, Ecker JR: Highly integrated single-base resolution maps of the epigenome in Arabidopsis. Cell 2008, 133:523-536.

78. Zilberman D, Coleman-Derr D, Ballinger T, Henikoff S: Histone H2A.Z and DNA methylation are mutually antagonistic chromatin marks. Nature 2008, 456:125-I29.

79. Mikkelsen TS, Ku M, Jaffe DB, Issac B, Lieberman E, Giannoukos G, Alvarez P, Brockman W, Kim TK, Koche RP, Lee W, Mendenhall E, O'Donovan A, Presser A, Russ C, Xie X, Meissner A, Wernig M, Jaenisch R, Nusbaum C, Lander ES, Bernstein BE: Genome-wide maps of chromatin state in pluripotent and lineage-committed cells. Nature 2007, 448:553-560.

80. Barski A, Cuddapah S, Cui K, Roh TY, Schones DE, Wang Z, Wei G, Chepelev I, Zhao K: High-resolution profiling of histone methylations in the human genome. Cell 2007, 129:823-837.

8I. Pokholok DK, Harbison CT, Levine S, Cole M, Hannett NM, Lee TI, Bell GW, Walker K, Rolfe PA, Herbolsheimer E, Zeitlinger J, Lewitter F, Gifford DK, Young RA: Genome-wide map of nucleosome acetylation and methylation in yeast. Cell 2005, 122:517-527.

82. Guenther MG, Levine SS, Boyer LA, Jaenisch R, Young RA: A chromatin landmark and transcription initiation at most promoters in human cells. Cell 2007, 130:77-88.

83. Ji H, Wong WH: TileMap: create chromosomal map of tiling array hybridizations. Bioinformatics 2005, 21:3629-3636.

84. UCSC Genome Bioinformatics [http://epigenom ics.mcdb.ucla.edu/H3K $4 \mathrm{~m} / \mathrm{m} 2 \mathrm{~m} 3 /]$ 